\begin{tabular}{|c|c|}
\hline 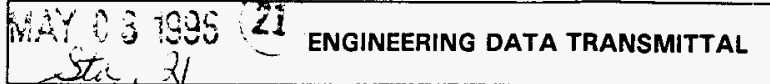 & 1. EDT No 614718 \\
\hline
\end{tabular}

2. To: (Receiving Organization)

Distribution

5. Proj./Prog./Dept./Div.:

HSI

8, Originator Remarks:

11. Receiver Remarks: Sitewide Systems Engineering

6. Cog. Engr.:

M. L. Grygiel
3. From: (originating organization)

4. Related EDT NO.:

$N / A$

7. Purchase Order No.: $N / A$

9. Equip./Component No.: N/A

10. System/Bldg./Facility: $N / A$

12. Major Assm. Dwg. No.: N/A

13. Permit/Permit Application No.: $N / A$

14. Required Response Date:

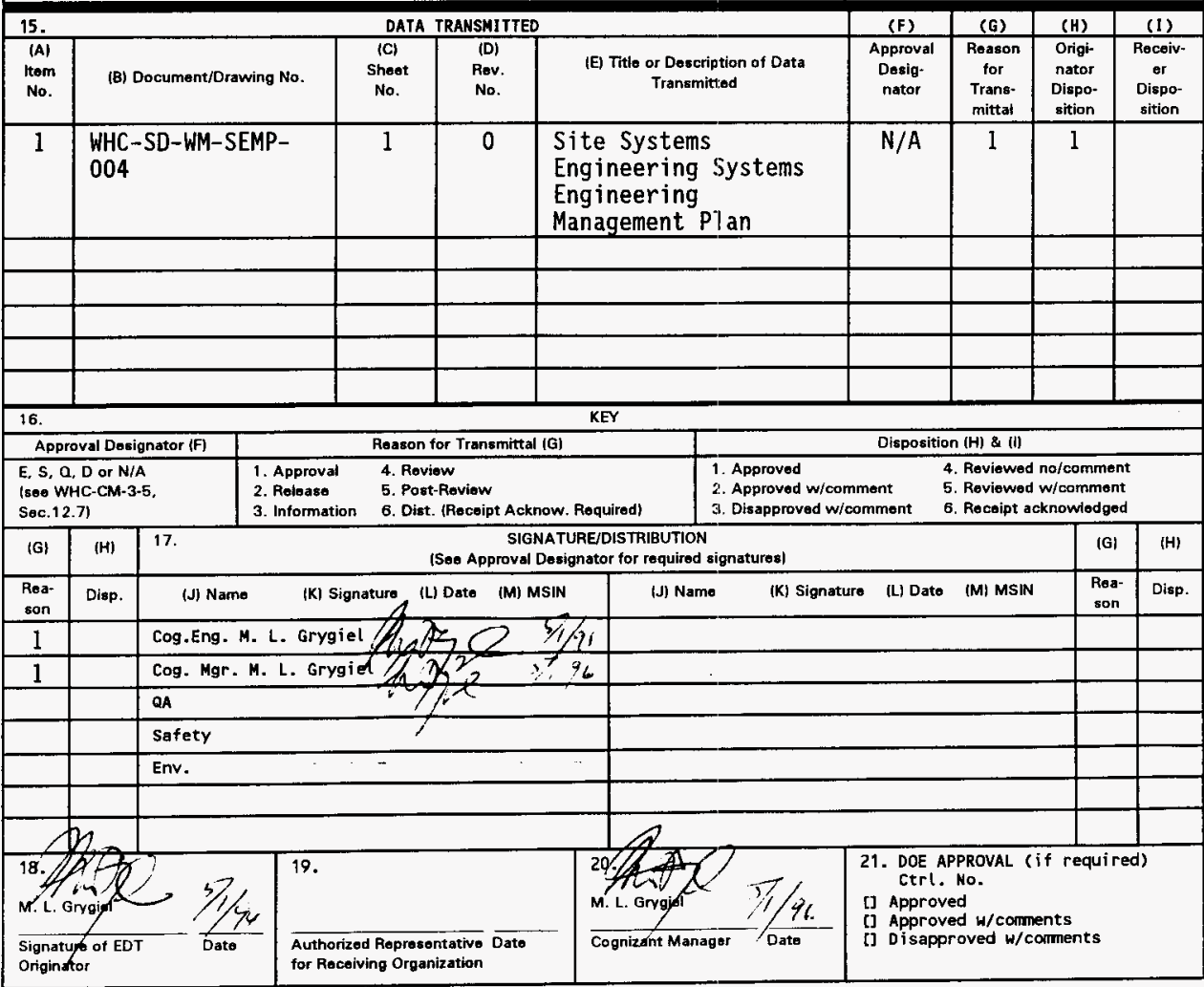




\title{
Site Systems Engineering Systems Engineering Management Plan
}

\author{
M. L. Grygiel \\ Westinghouse Hanford Company, Richland, WA 99352 \\ U.S. Department of Energy Contract DE-AC06-87RL10930 \\ EDT/ECN: 614718 \\ UC: \\ Org Code: 02100 \\ Charge Code: Y2D01 \\ B\&R Code: EW3120075 \\ Total Pages: 59 \\ Kri
}

Key Words: Systems Engineering, Hanford Site Technical Baseline, Interface Control Documents, Document Hierarchy, Multi-Year Program Plan,

Abstract: The Site Systems Engineering Management Plan (SEMP) is the Westinghouse Hanford Company (WHC) implementation document for the Hanford Site Systems Engineering Policy, (RLPD 430.1) and Systems Engineering Criteria Document and Implementing Directive, (RLID 430.1). These documents define the U.S. Department of Energy (DOE), Richland Operations office (RL) processes and products to be used at Hanford to implement the systems engineering process at the site level. This SEMP describes the products being provided by the site systems engineering activity in fiscal year (FY) 1996 and the associated schedule. It also includes the procedural approach being taken by the site level systems engineering activity in the development of these products and the intended uses for the products in the integrated planning process in response to the DOE policy and implementing directives.

TRADEMARK DISCLAIMER. Reference herein to any specific commercial product, process, or service by trade name, trademark, manufacturer, or otherwise, does not necessarily constitute or imply its endorsement, recomendation, or favoring by the United States Government or any agency thereof or its contractors or subcontractors.

Printed in the United States of America. To obtain copies; of this document, contact: WHC/BCS Document Control Services, P.O. Box 1970, Mailstop H6.08, Richland WA 99352, Phone (509) 372-2420; Fax (509) 376-4989.
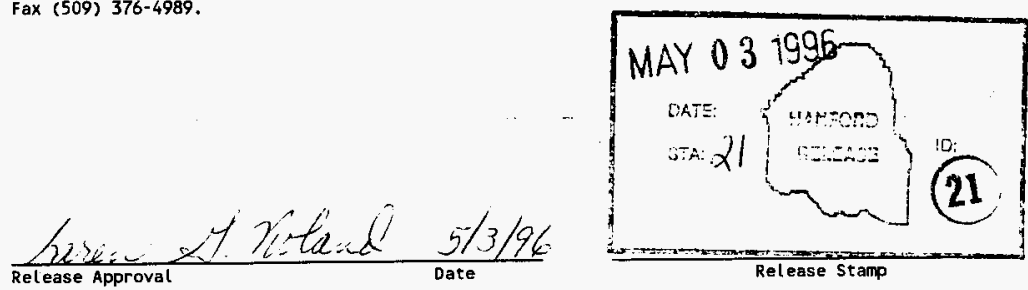

Approved for Public Release 


\section{SITE SYSTEMS ENGINEERING SYSTEMS ENGINEERING MANAGEMENT PLAN}

\section{CONTENTS}

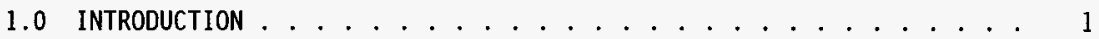

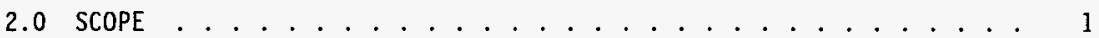

3.0 MAJOR PRODUCTS FOR FISCAL YEAR $1996 \ldots \ldots \ldots \ldots$

3.1 THE HANFORD SITE TECHNICAL BASELINE $\ldots \ldots \ldots$

3.2 THE DRAFT HANFORD SITE CLEANUP SPECIFICATION $\ldots \ldots \ldots$

3.3 INTERFACE CONTROL DOCUMENTS . . . . . . . . . . . 2

3.3.1 Introduction . . . . . . . . . . . . . . . . 2

3.3.2 Hierarchy of Documents . . . . . . . . . . . 5

3.4 SITE SYSTEMS ANALYSES . . . . . . . . . . . . . . . 11

3.5 ISSUE RESOLUTION AND TRACKING . . . . . . . . . . . 11

3.5 .1 Introduction ............... 11

3.5.2 Description of Process Steps . . . . . . . . . 14

3.5.3 Definitions . . . . . . . . . . . 17

3.6 SITEWIDE SYSTEMS ENGINEERING INTEGRATION GROUP . . . . . . 17

4.0 PerformanCE logic AND SCHEdULE . . . . . . . . . . . . 17

5.0 INTEGRATION OF HSTB WITH THE MYPP PROCESS . . . . . . . . . . 20

5.1 INTRODUCTION . . . . . . . . . . . . . . . . 20

5.2 TECHNICAL BASELINE $\ldots \ldots \ldots \ldots \ldots \ldots \ldots . \ldots . \ldots 20$

5.2.1 Project Mission ........... . . . 20

5.2.2 Project Technical objectives . . . . . . . . . 20

5.2 .3 Forecasting Data . . . . . . . . . . . 22

5.2 .4 Drivers ................ . . 24

5.2.5 Project Life-Cycle Requirements . . . . . . . 24

5.2.6 Project Issues and Assumptions .......... 25 


\section{LIST OF FIGURES}

1 Hanford Site Cleanup Specification Development . . . . . . . . . . 4

2 Hanford Site Interface Document Hierarchy . . . . . . . . . 6

3 Hanford System Hierarchy ................... 12

4 Issue Resolution Process . . . . . . . . . . . . . . 13

5 FY 1996 Site Technical Integration Logic . . . . . . . . . . . 18

6 Develop Site Specification . . . . . . . . . . . . 19

7 Multi-Year Program Planning Guidance - Techniical Baseline . . . . . . 21

\section{LIST OF TABLES}

1 Sitewide Systems Engineering Project List . . . . . . . . . . . 3

2 Hanford Site Cleanup Interface Control Document Matrix . . . . . . 7

3 Project Hanford and Interface Data Elements . . . . . . . . . 8 


\section{SITE SYSTEMS ENGINEERING \\ SYSTEMS ENGINEERING MANAGEMENT PLAN}

\subsection{INTRODUCTION}

The Site Systems Engineering Management Plan (SEMP) is the Westinghouse Hanford Company (WHC) implementation document for the Hanford Site Systems Engineering Policy, (RLPD 430.1) and Systems Engineering Criteria Document and Implementing Directive, (RLID 430.1). These documents define the U.S. Department of Energy (DOE), Richland Operations Office (RL) processes and products to be used at Hanford to implement the systems engineering process at the site level. They are included in Appendix A to this SEMP. This SEMP describes the products being provided by the site systems engineering activity in fiscal year (FY) 1996 and the associated schedule. It also includes the procedural approach being taken by the site level systems engineering activity in the development of these products and the intended uses for the products in the integrated planning process in response to the DOE policy and implementing directives. (See Use of Technical Baseline Data in the Multi-Year Program Plan [MYPP] preparation described in the WHC Budget Formulation Manual.)

\subsection{SCOPE}

The scope of the systems engineering process described in this SEMP is to define a set of activities and products to be used at the site level during FY 1996 or until the successful Project Hanford Management Contractor (PHMC) is onsite as a result of contract award from Request For Proposal

DE-RP06-96RL13200. Following installation of the new contractor, a long-term set of systems engineering procedures and products will be defined for management of the Hanford Project. The extent to which each project applies the systems engineering process and the specific tools used are determined by the project's management.

\subsection{MAJOR PRODUCTS FOR FISCAL YEAR 1996}

In response to $R L P D / R L I D 430.1$, the site systems engineering organization is developing five major products.

\subsection{THE HANFORD SITE TECHNICAL BASELINE}

The Hanford Site Technical Baseline (HSTB) is the core of the systems engineering activity at the site level. It contains a technical description of the Hanford Project. This description consists of functional elements down to a selected project level, as well as input-output data among these elements (including waste type data where it exists), requirements derived both from the top down strategic level and rolled up from the requirements that exist in 
the FY 1996 MYPP documentation, and schedule data relevant to the functional elements. The HSTB also contains the Project Hanford structure into which the above information will be mapped.

Because the information in the HSTB is still evolving, there are a number of inconsistencies and disconnects in it. These result in issues to be resolved as described in Section 3.5 below.

\subsection{THE DRAFT HANFORD SITE CLEANUP SPECIFICATION}

The Hanford Site Cleanup Specification forms the basis of agreement between RL and the Contractors on the technical performance requirements for execution of the Site mission. It also forms the basis for the development of the lower level project requirements documents. In FY 1996 the site specification will contain a requirements set derived from the strategic level documentation allocated to a subset of the Project Hanford structure shown in Table 1. It will also contain a rolled-up set of requirements derived from the existing project MYPP's.

The structure of the site specification and its relationship to lower level requirements is shown in figure 1 .

\subsection{INTERFACE CONTROL DOCUMENTS}

\subsubsection{Introduction}

Interfaces exist where wastes, materials, and facilities cross function and project boundaries. Interface Control Documents (ICDs) are used as a management tool to:

- Formally define and control interfaces;

- Identify inconsistencies in assumptions between Projects;

- Identify and track material and waste flow between Projects;

- Integrate inter-Project planning input to the MYPPs;

- Support the integration and validation of the HSTB;

- Improve management and cost effectiveness of Project designs relative to interfaces between Projects.

At Hanford, ICDs will be used to link the Projects that make up Project Hanford by defining the physical interactions between Projects, as well as the Project critical needs for services and infrastructure. ICDs will contain specific definitions of waste and material flows so that sending and receiving projects have a common understanding of material,..quantity, and timing. They will also contain physical property information such as concentrations and size. This information will comprise an integrated technical view of the site for management purposes. 
Table 1. Sitewide Systems Engineering Project List.

May 1,1996

\begin{tabular}{|c|c|c|c|c|}
\hline TANK WASTE REMED IATION SYSTEM & HASTE MANAGEMENT & FACILITY TRANSITION & ENVIRONMENTAL RESTORATION & TECHHOLOGY MANAGEMENT \\
\hline 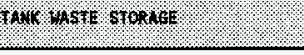 & SPENT FUELS & 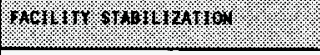 & $\begin{array}{l}\text { DECONTAMINATION AND } \\
\text { DECOMMI SSION ING }\end{array}$ & TECHNOLOGY DEVELOPMENT \\
\hline Iank Waste Characterization & 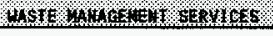 & PUREX & GROUNDHATER MANAGEMENI & 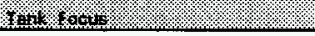 \\
\hline Tank Safety issue Resolution & Sol id Waste & PFP & REMEDIAL ACIION & $\begin{array}{l}\text { ENVIRONMENTAL MOLECULAR } \\
\text { SCIENCES LABDRATORY (EMSL) }\end{array}$ \\
\hline Tank Farms Operations & Liquid Effluents & $\begin{array}{l}\text { FFIF/Legacy Facilities/Special } \\
\text { Initiatives }\end{array}$ & $\begin{array}{l}\text { ENVIRONMENTAL RESTORATION } \\
\text { DISPOSAL FACILITY } \\
\end{array}$ & 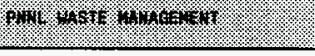 \\
\hline 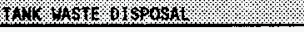 & Analytical Services & B Plant/NESF & N AREA & 324 B Cell Cleanout \\
\hline Tank Waste Retrieval & 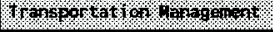 & 300 Area/SHM & & German Log Disposat \\
\hline Low Level Tank Haste & & 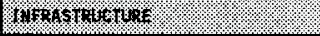 & & High-level Vault Tanks \\
\hline High Level Tank Waste & & $\begin{array}{l}\text { Infrastructure Operations and } \\
\text { Maintenance }\end{array}$ & & 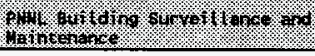 \\
\hline botsposal $18 \%$ & & $\begin{array}{l}\text { Real Estate and Property } \\
\text { Management }\end{array}$ & & \\
\hline HLW Interim Storage & & 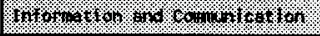 & & \\
\hline $\begin{array}{l}\text { LLW storage and } \\
\text { Disposal }\end{array}$ & & HAMMER & & \\
\hline $\begin{array}{l}\text { Cs \& Sr Capsule } \\
\text { Disposition }\end{array}$ & & & & \\
\hline
\end{tabular}

Non-shaded projects represent the level at which Sitewide Systems Engineering data will be collected and interfaces defined. 


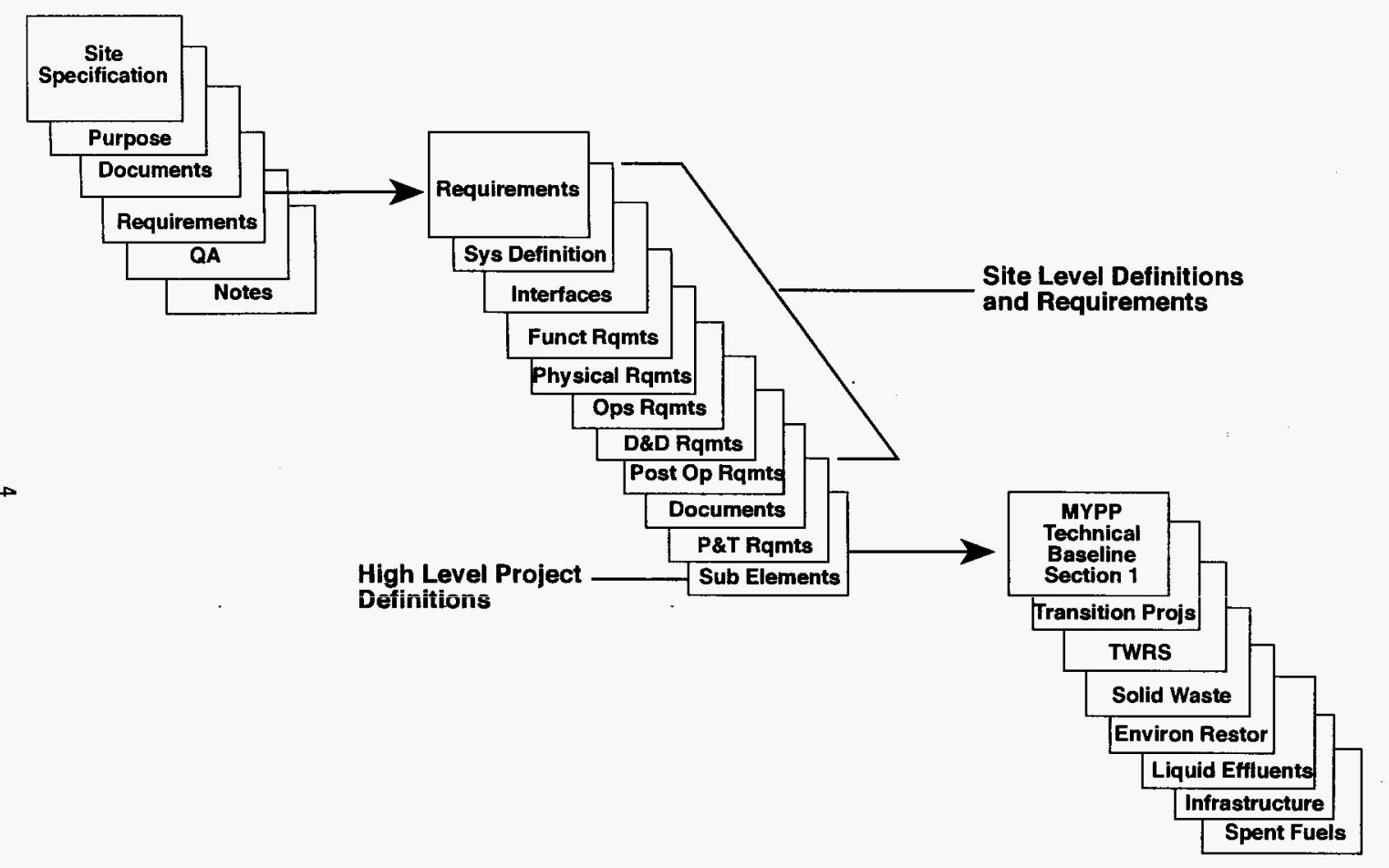

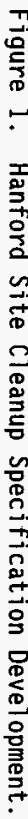

B960100.12 


\subsubsection{Hierarchy of Documents}

The amount of interface information for Project Hanford is enormous. To accommodate this, a hierarchical structure of information has been developed as shown in Figure 2. This hierarchy of Interface Documents consists of:

1. Hanford Site Cleanup ICD Matrix (Super ICD)

2. Memorandums of Understanding (MOUs)

3. Physical ICDs.

The Super ICD will be developed by Sitewide Systems Engineering (SWSE). MOUs and Physical ICDs will be developed and maintained by the Hanford Projects.

Table 2 contains the minimum information that will be contained in the Super ICD. Table 3 contains the primary data elements and Projects that have functional interfaces. MOUs shall be developed for each of the unshaded areas. Physical ICDs will be developed at the Projects' discretion.

\subsubsection{Hanford Site Cleanup Interface Control Document Matrix (Super ICD).} The Super ICD is a management toot and framework for identifying and managing interfaces for Project Hanford. It is a Site level index of functional interfaces (data elements) as defined in the HSTB and it provides a matrix of data elements between projects for the life-cycle of the Hanford Cleanup Mission. The matrix shows where MOUs are required between Projects.

The Super ICD will contain the following: Introduction, definition of terms, Hanford Projects $\mathrm{N}^{2}$ Diagrams, and Data Element Interface information. For each external and internal interface (data element), the information described in Table 1 will be collected.

SWSE will generate the tables of information for the Super ICD from the HSTB database. The Project representatives are responsible for providing the requested information, reviewing the HSTB outputs, and maintaining the information current via change control.

3.3.2.2 Hanford Site Memorandums of Understanding (MOUs). MOUs are used to document the interface agreements between Projects. Each functional interface between Projects shall be documented by a MOU.

The Projects are responsible for writing MOUs according to the guidelines contained in the existing Systems Engineering procedures. A "Graded Approach" should be used when implementing these procedures. The general principle to follow is that the MOUs should be initiated by the sending Project.

3.3.2.3 Hanford Site Physical Interface Control Documents (Physical ICDs). The Physical ICDs are used to document the physical implementation of the interface. These ICDs provide the most detailed information that the Projects feel is necessary to effectively manage the functional interfaces. Physical ICDs should be prepared wherever the Projects decide they are needed. 


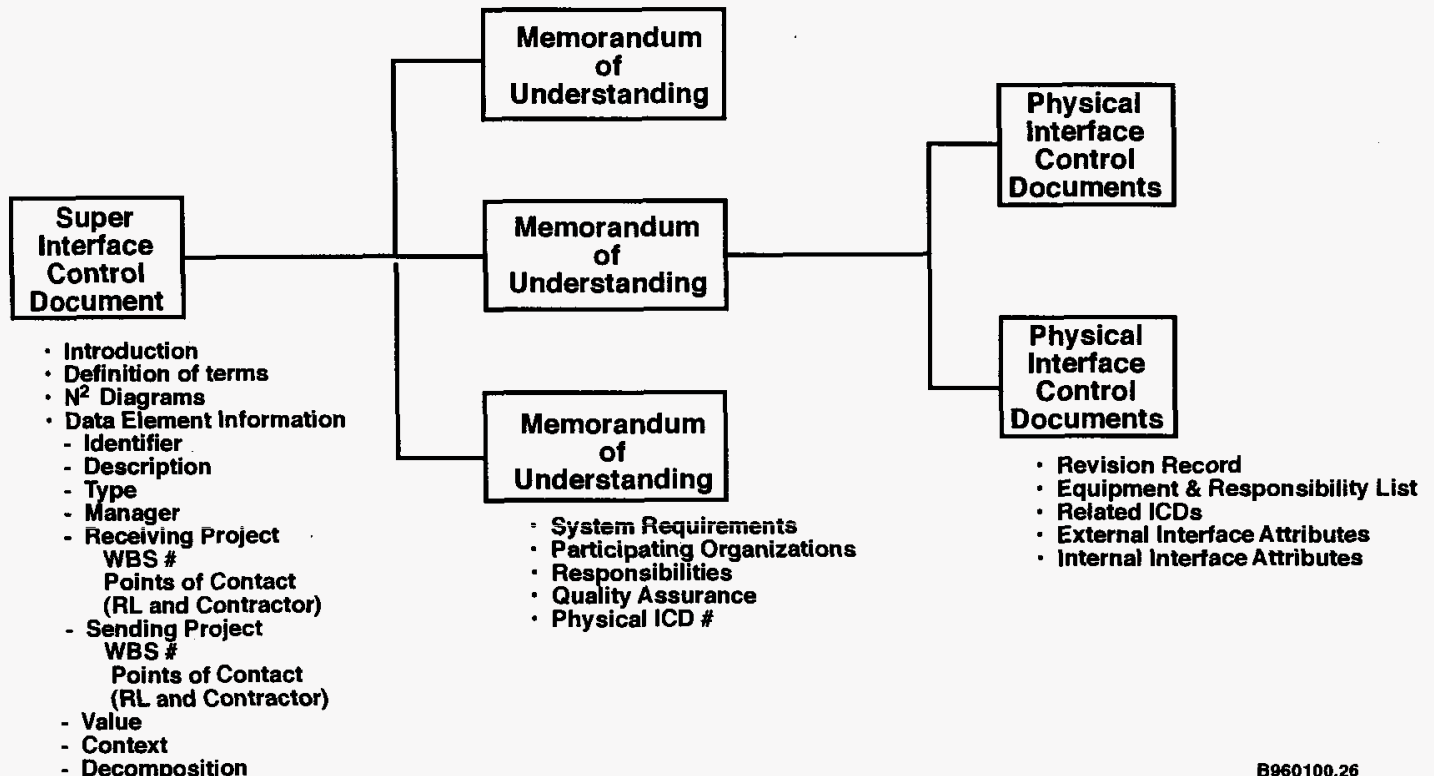

- Decomposition

B960100.26 
Table 2. Hanford Site Cleanup Interface Control Document Matrix.

\begin{tabular}{|c|c|}
\hline IDENTIFIER & $\begin{array}{l}\text { This is the unique naming identifier assigned to the data element } \\
\text { (e.g. Tank Waste, Solid Waste) }\end{array}$ \\
\hline DESCRIPTION & This is a description of the Data Element \\
\hline TYPE & $\begin{array}{l}\text { This field categorizes the data element. Data elements enter or exit } \\
\text { a function that is performed by some component within a Project. } \\
\text { Date element types include: Control, Input, Output, or Mechanism. }\end{array}$ \\
\hline MANAGER & $\begin{array}{l}\text { The name of the Primary Data Element Manager. This is typically the } \\
\text { Program manager for the receiving Project }\end{array}$ \\
\hline RECEIVING PROJECT & Receiving Project name from Project Hanford report \\
\hline HBS \# & Project WBS number that covers work associated with this data element \\
\hline $\begin{array}{l}\text { POINTS OF CONTACT } \\
\text { (RL and Contractor) }\end{array}$ & $\begin{array}{l}\text { The individuals within an organization that coordinate the interfaces } \\
\text { and information exchanges. Iypically the DOE monitor and the } \\
\text { Contractor Cognizant Engineer }\end{array}$ \\
\hline SENDING PROJECT & Sending Project name from Project Hanford report \\
\hline WBS \# & Project WBS number that covers work associated with this data element \\
\hline $\begin{array}{l}\text { POINTS of CONTACT } \\
\text { (RL and Contractor) }\end{array}$ & $\begin{array}{l}\text { The individual within an organization that coordinates the interfaces } \\
\text { and information exchanges. Typically the DOE monitor and the } \\
\text { Contractor Cognizant Engineer }\end{array}$ \\
\hline START AND FINISH DATE & $\begin{array}{l}\text { The year the data element starts being transferred and the year the } \\
\text { data elements stops being transferred. }\end{array}$ \\
\hline VALUE & Ident if ies minimum, mean, and maximum values for the data element. \\
\hline CONTEXT & $\begin{array}{l}\text { Identifies references to higher level data element that this data } \\
\text { element is a constituent of (e.g., Pretreated LLW for Immobilization } \\
\text { is a constituent of Pretreated Waste) }\end{array}$ \\
\hline DECOMPOSITION & $\begin{array}{l}\text { Identifies other data elements that this data element decomposes to } \\
\text { (e.g.' Pretreated Waste decomposes to Pretreated LLW for } \\
\text { Immobilization and Pretreated HLW for Immobilization). }\end{array}$ \\
\hline TABLES & $\begin{array}{l}\text { The data element table provides a tabular format to show the } \\
\text { Function, Project, MOU, and ICD. relationships to a data element. } \\
\text { Table } 1.1 \text { is an example data element table. }\end{array}$ \\
\hline MOU \# & The number and title of the MOU that covers this data element \\
\hline
\end{tabular}


Table 3. Project Hanford and Interface Data Elements.

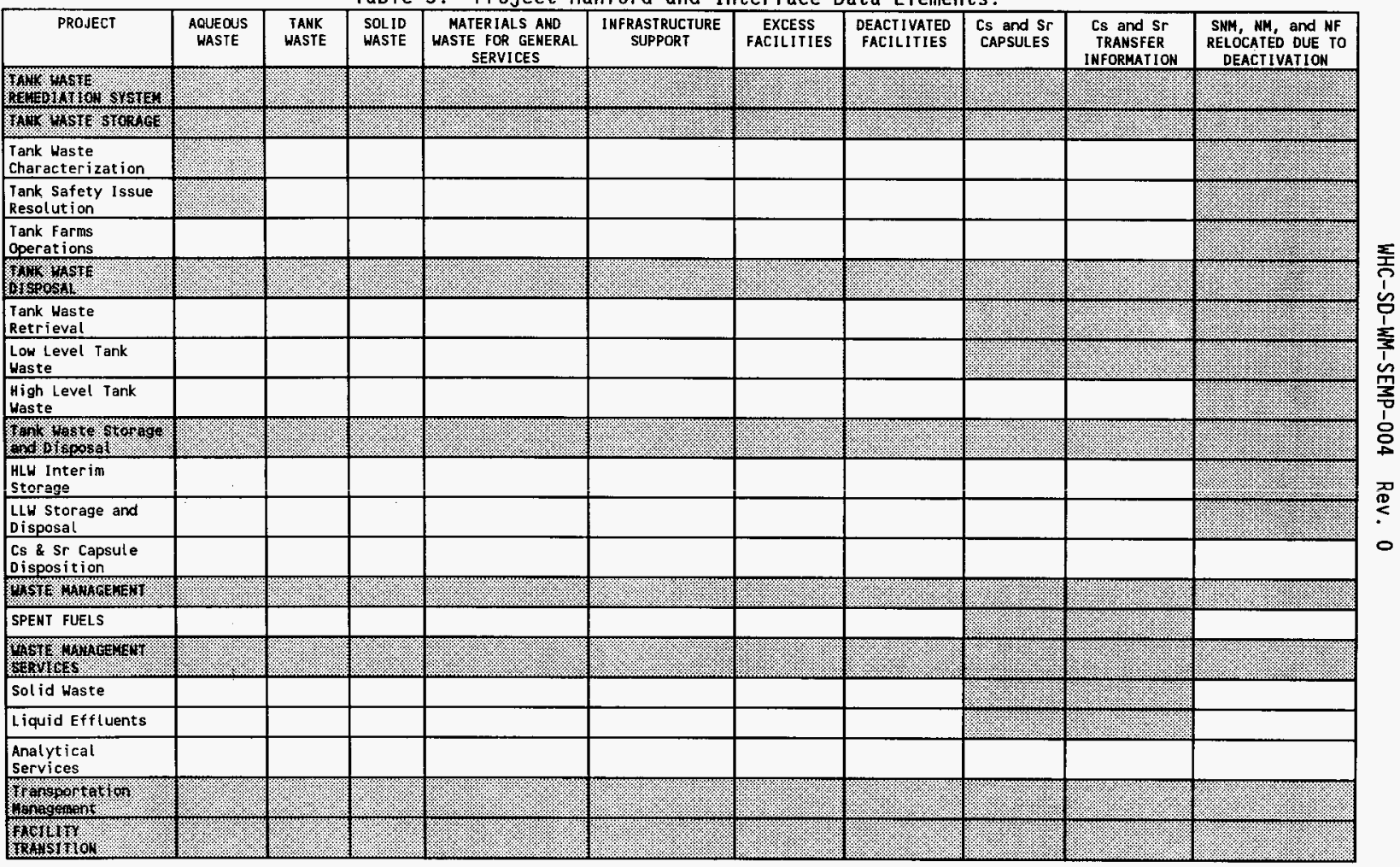


Table 3. Project Hanford and Interface Data Elements.

\begin{tabular}{|c|c|c|c|c|c|c|c|c|c|c|}
\hline PROJECT & $\begin{array}{l}\text { AQUEOUS } \\
\text { WASTE }\end{array}$ & $\begin{array}{l}\text { TANK } \\
\text { WASTE }\end{array}$ & $\begin{array}{l}\text { SOLID } \\
\text { WASIE }\end{array}$ & $\begin{array}{c}\text { MATERIALS AND } \\
\text { WASTE FOR GENERAL } \\
\text { SERVICES } \\
\end{array}$ & $\begin{array}{l}\text { INFRASTRUCTURE } \\
\text { SUPPORT }\end{array}$ & $\begin{array}{c}\text { EXCESS } \\
\text { FACILITIES }\end{array}$ & $\begin{array}{l}\text { DEACTIVATED } \\
\text { FACILITIES }\end{array}$ & $\begin{array}{l}\text { Cs and } s r \\
\text { CAPSULES }\end{array}$ & $\begin{array}{l}\text { Cs and } S r \\
\text { TRANSFER } \\
\text { INFORMATION }\end{array}$ & $\begin{array}{l}\text { SNM, NM, and NF } \\
\text { RELOCATED DUE TO } \\
\text { DEACTIVATION }\end{array}$ \\
\hline Kal I I I & & & & & (2) & 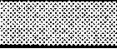 & & & & (2: \\
\hline $\begin{array}{l}\text { PUREX } \\
\end{array}$ & & & & & & & & & & \\
\hline PFP & & & & & & & & 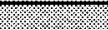 & & \\
\hline $\begin{array}{l}\text { FFTF Legacy } \\
\text { Facilities and } \\
\text { Special } \\
\text { Initiatives } \\
\end{array}$ & & & & & & & & & & \\
\hline$B$ Plant and WESF & & & & & & & & & & 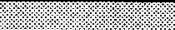 \\
\hline 300 Area SNM & & & & & & & & & & \\
\hline 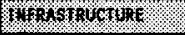 & 10.8 & 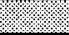 & (2.:-2.: & 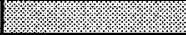 & & 25. & W. & 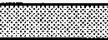 & (2) & \\
\hline $\begin{array}{l}\text { Infrastructure } \\
\text { Operat ions and } \\
\text { Maintenance }\end{array}$ & & & & & & & & & & \\
\hline $\begin{array}{l}\text { Real Estate and } \\
\text { Property } \\
\text { Management }\end{array}$ & & & & & & & & & & \\
\hline 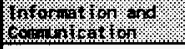 & 1.2 .6 .2$. & $\sqrt{4}$ & $\sqrt{2}$ & : & . & & 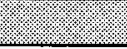 & & & \\
\hline 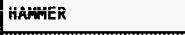 & & & & & & & & m & W. & \% \\
\hline 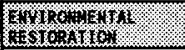 & & & & (2. & 13.9 & 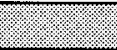 & 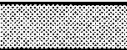 & & & 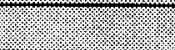 \\
\hline $\begin{array}{l}\text { DECONTAMI NATION } \\
\text { AMD } \\
\text { DECOMMIISSIONING }\end{array}$ & ? & & & & & & & & & \\
\hline $\begin{array}{l}\text { GROUNDWATER } \\
\text { MANAGEMENT } \\
\end{array}$ & & & & & & & & & & \\
\hline REMEDIAL ACTION & & & & & & & & 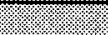 & & 10 \\
\hline $\begin{array}{l}\text { ENVIRONMENTAL } \\
\text { RESTORAT ION } \\
\text { DISPOSAL FACILITY }\end{array}$ & & & & & & & & & & \\
\hline N AREA & & & & & & & & \%? & 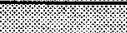 & \\
\hline 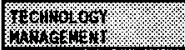 & & & & & & & & & & \\
\hline $\begin{array}{l}\text { TECHNOLOGY } \\
\text { DEVELOPMENT }\end{array}$ & & & & & & & & & & \\
\hline
\end{tabular}


Table 3. Project Hanford and Interface Data Elements.

\begin{tabular}{|c|c|c|c|c|c|c|c|c|c|c|}
\hline PROJECT & $\begin{array}{l}\text { AQUECUS } \\
\text { HASTE }\end{array}$ & $\begin{array}{l}\text { TANK } \\
\text { WASTE }\end{array}$ & $\begin{array}{l}\text { SOLID } \\
\text { WASTE }\end{array}$ & $\begin{array}{c}\text { MATERIALS AND } \\
\text { WASTE FR GENERAL } \\
\text { SERVICES }\end{array}$ & $\begin{array}{l}\text { INFRASTRUCTURE } \\
\text { SUPPORT }\end{array}$ & $\begin{array}{l}\text { EXCESS } \\
\text { FACILITIES }\end{array}$ & $\begin{array}{l}\text { DEACTIVATED } \\
\text { FACILITIES }\end{array}$ & $\begin{array}{l}\text { Cs and Sr } \\
\text { CAPSULES }\end{array}$ & $\begin{array}{l}\text { Cs and } s r \\
\text { TRANSER } \\
\text { IMFORMAT ION }\end{array}$ & $\begin{array}{l}\text { SNM, NM, and NF } \\
\text { RELOCATED DUE TO } \\
\text { DEACTIVATION }\end{array}$ \\
\hline 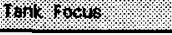 & 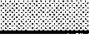 & 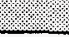 & & 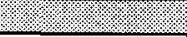 & & . & 4 & & i. & 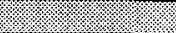 \\
\hline $\begin{array}{l}\text { ENVIROMMENTAL } \\
\text { MOLCULAR SCIENCE } \\
\text { LABORATORY (EMSL) }\end{array}$ & & & & & & & & & & \\
\hline 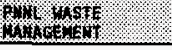 & & & & & & & & & & \\
\hline $\begin{array}{l}324 \text { B Cell } \\
\text { Cleanout }\end{array}$ & & & & & & & & & & \\
\hline $\begin{array}{l}\text { German Log } \\
\text { Disposal }\end{array}$ & & & & & & & & & & \\
\hline $\begin{array}{l}\text { High-level Vault } \\
\text { Tanks }\end{array}$ & & & & & & & & & & \\
\hline 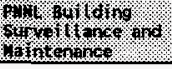 & & & & & & & & & & \\
\hline
\end{tabular}

เ 
The Projects are responsible for writing Physical ICDs according to the guidelines contained in the existing Systems Engineering procedures. A "Graded Approach" should be used when implementing these procedures. The general principle to follow is that the Physical. ICDs should be initiated by the sending Project.

\subsection{SITE SYSTEMS ANALYSES}

The Site Systems Analyses (SSA) is a dynamic simulation of the HSTB for the complete life-cycle of the cleanup mission. It adds the elements of time and resource interdependencies to the static information in the HSTB. It is used to verify that the HSTB is viable in that capabilities and facilities are available when needed and can handle the materials needed in the time required. It also verifies the interfaces and other information in the HSTB. The SSA will be developed for the elements shown in Figure 3 . As with other portions of the site systems engineering activities inconsistencies identified in the SSA will result in issues to be resolved by the affected programs.

\subsection{ISSUE RESOLUTION AND TRACKING}

\subsubsection{Introduction}

The issue resolution and tracking process provides a tool for tracking and prioritization of issues identified through the systems engineering process described in this document, as well as issues identified through other planning activities at Hanford.

The cleanup mission at Hanford is very large and complex and there are a number of obstacles that prevent Hanford from accomplishing the mission. These obstacles, called issues, cut across Hanford Projects and Services, as well as other DOE sites. Whether the issues are simple or complex, there must be a consistent and systematic process for resolving them. Figure 4 shows the approach that will be used by the Sitewide Systems Engineering Integration Group (SWSEIG) to track site-level issues.

The focus of SWSE issue resolution is on conflicts or discontinuities in requirements and planning assumptions, omissions in project or service baselines, or interface compatibility issues. This process will be used to resolve issues (final decisions) or establish planning assumptions (interim decisions) associated with issues that impact more than one major project or service. A limited, select number of technical issues that are not crosscutting may be reported on the Sitewide Issue Resolution Status Report (Risk Management List [RML]). Typically, subordinate risks and issues will be identified and managed by the individual Project or Service as necessary.

Significant or cross-cutting issues that cannot be resolved at the Project or Service level shall be elevated to the Site Management Board (SMB) for resolution. 
Figure 3. Hanford System Hierarchy.

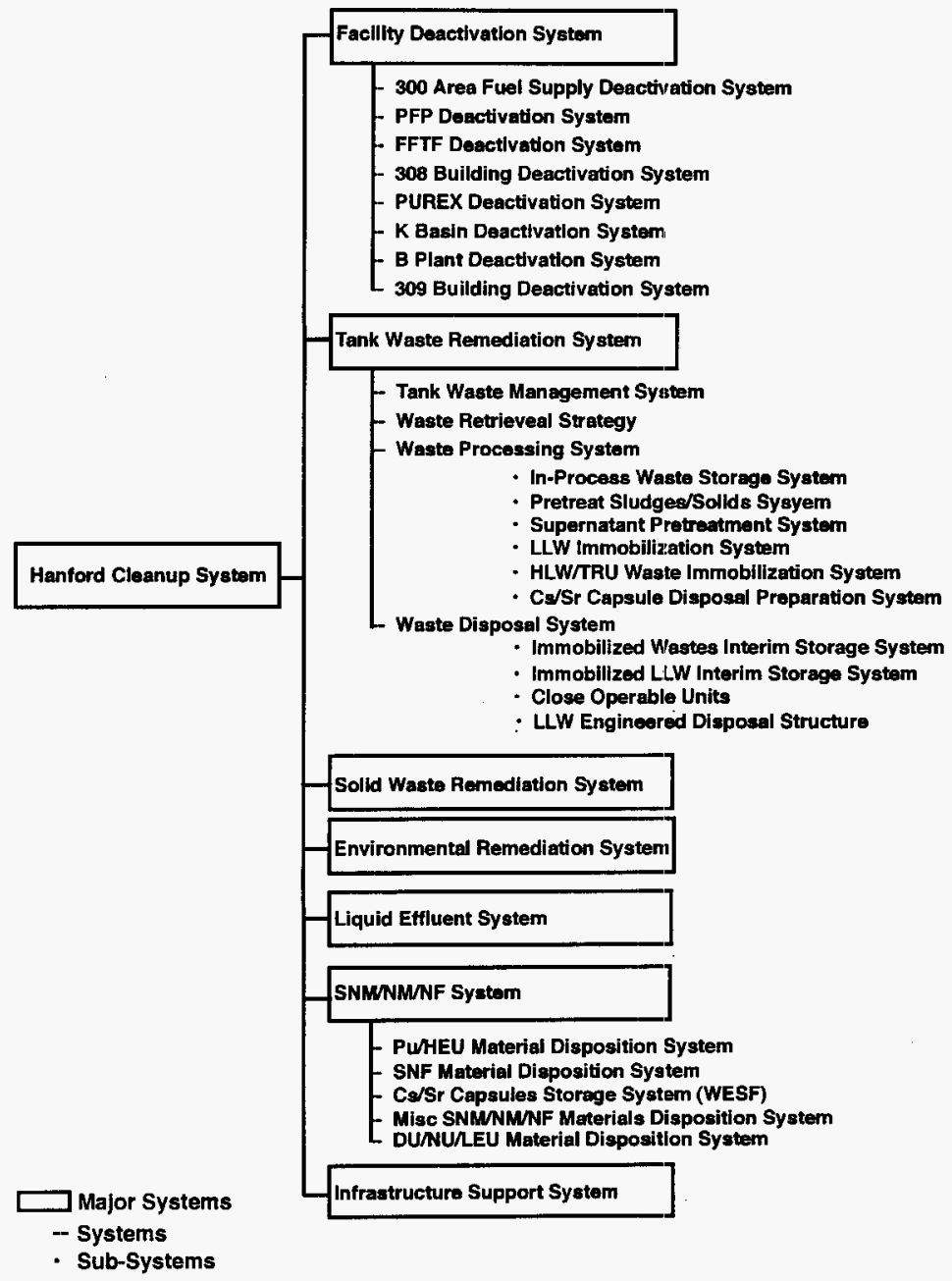


etrotosos6a

Jaumo/uộdueys $\square$

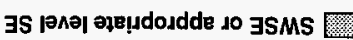

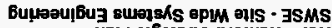
UEld गॄ6elens puojueH - dSH

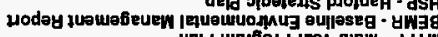

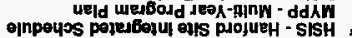

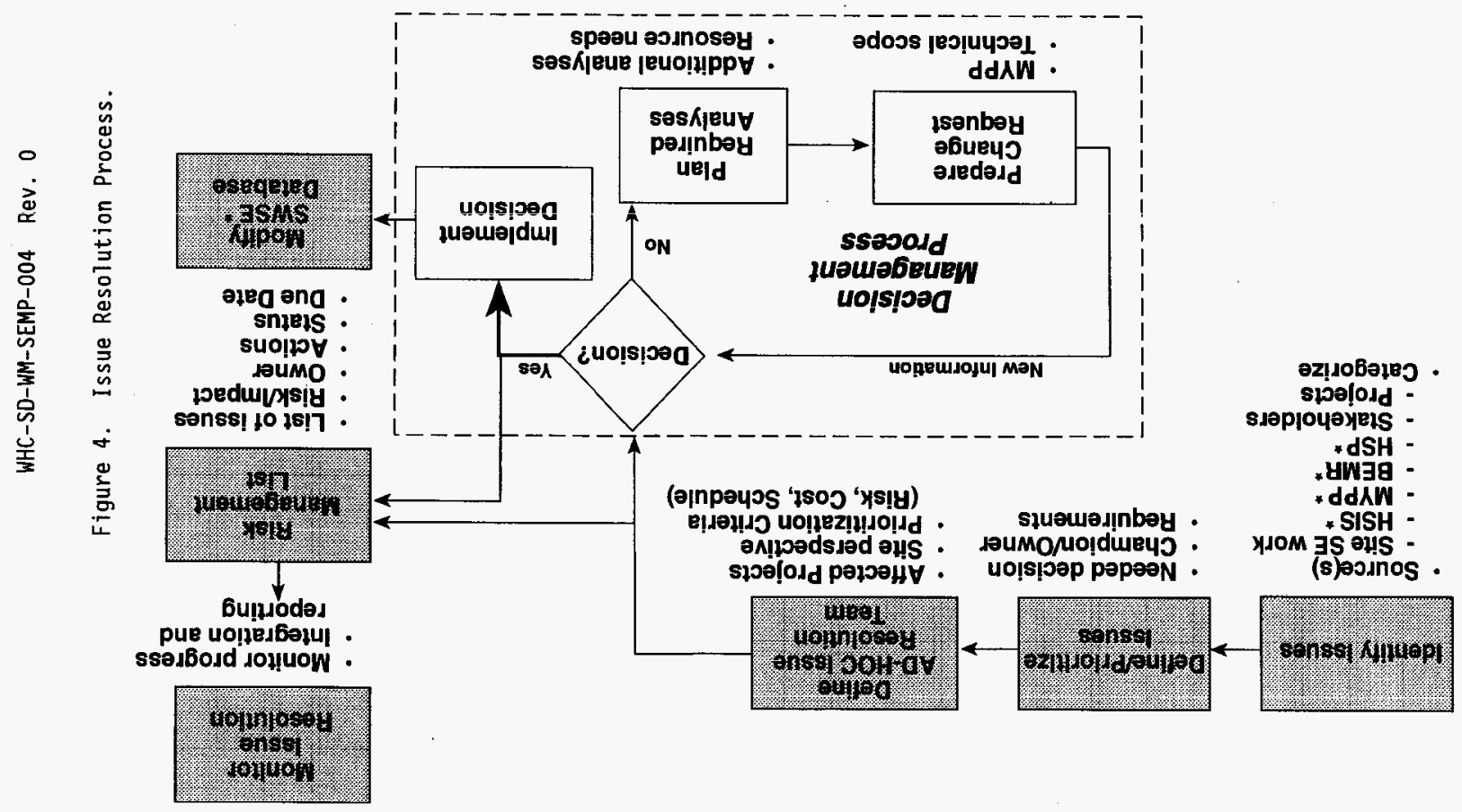


WHC-SD-WM-SEMP-004 Riev. 0

\subsubsection{Description of Process Steps}

Figure 4 shows a step-by-step process for resolving the issues. The contents of each step will vary with the complexity of the issue. The shaded steps are the responsibility of systems engineering at the appropriate level. The following sections describe each step.

3.5.2.1 Identify Issue. There are several sources of issues that affect the HSTB and they are identified in many ways. Some typical sources of issues are:

SWSE, Hanford Site Integrated Schedule, MYPPs, Baseline

Environmental Management Report, Hanford Strategic Plan, Stakeholders, and Projects. As SWSE data is developed and analyzed by Projects or Services, the SWSEIG, SWSE personnel, Planning and Integration Division personnel, and others, issues requiring resolution will be identified. These may include issues impacting multiple Projects or Services or an issue that has a major impact on a single Project or Service.

During this step the source of the issue is identified and the issue is categorized. At the site level there are four major categories of issues.

1. Land Use

2. Material Disposition

3. Newly received offsite waste

4. Other site missions.

Land Use and Material Disposition categories are further divided into sub-categories that are aligned with the Hanford Projects to ensure proper assignment of responsibilities.

The categories provide a hierarchy framework for issue prioritization. This is useful because if a top-level issue is not resolved and is fairly fluid, resolution of lower-level issues is more difficult.

3.5.2.2 Define and Prioritize Issue. A clear definition of the issue is essential to develop the resolution requirements. The definition shall include a concise statement of the issue, background that created the issue, resolution requirements, and required decision. The extent and potential severity of consequences related to the issue shall be defined. Technical, programmatic, cost, safety, and other impacts will be described. Based upon the programmatic and cost impacts, the priority and timing for the issue resolution will be defined.

The SWSE group will. determine if the issue. is significant enough to include in the tracking system and what level of tracking is appropriate.

3.5.2.3 Define Ad hoc Issue Resolution Team. The owner, champion, and affected site Projects or Services will be identified by the SWSEIG and included in the ad hoc issue resolution team. The Project or Service that takes the lead for the resolution will assign a "champion" who will be responsible for the issue resolution and closure. The champion is the ad hoc team leader and is responsible for involving the cross-cutting Projects or 
Services that are impacted by the issue. Requests to change leadership or members of the ad hoc team will be made to the SWSEIG.

This team will consist of the champion(s) from the responsible organization(s), other affected project(s) representatives, SWSE representative, and technology development representative. This team will be responsible for: 1) assigning a priority to the issue, based upon established criteria; 2) preparing a decision package for the decision maker, and 3) providing additional information if requested by the decision maker. Each ad hoc team will be dissembled after the decision is made and implemented.

3.5.2.4 Monitor Issue Resolution. SWSE will monitor the issue resolution work using the RML. Progress will be reported routinely to the SWSEIG and a monthly status report on the critical issues will be provided to the SMB.

3.5.2.5 Risk Management List. The Sitewide Issue Resolution Status Report (RML) will be maintained as part of the HSTB. The list will be printed from the database on an as-needed basis. The HSTB is maintained under configuration control in accordance with the guiding procedure. It is updated by SWSE as issues are added, changed, or completed. SWSE will maintain the RML at the site and Project interface levels. Each Project and Service may maintain their own RML for internal issues.

The RML is a matrix (table) that lists all the current issues and shows the status of each issue. The matrix includes information on the priority (impacts), champion, owner, due date, and status of the issues. The RML may contain two levels of issues: the Critical RML, and the RML. The Critical RML will be sent to the RL SMB monthly with significant changes or delinquencies noted.

3.5.2.6 Modify Hanford Site Technical Baseline. When a decision is made, the implementation includes preparing a change request to the HSTB. Completed resolutions will be carried on the RML until the HSTB is modified with an approved change request. The champion is responsible for preparing the change request and getting it approved and SWSE will update the database from the change request.

3.5.2.7 Decision. Issues are resolved using the RL decision management process and there are multiple routes to a decision in RL depending on the decision to be made and the appropriate decision-making authority or authorities.

The approach for SWSE-related decisions is not to prescribe specific procedures to be followed, but to recognize the existence of multiple valid paths and focus on the path to obtain a corporate review of a specific issue and decision where that review is supported by a member of the RL SMB.

The ad hoc team will determine the appropriate course of action and schedule to resolve the issue. The champion shall prepare a package for the decision maker(s) that will include the definition, priority, and urgency of the issue. A recommended decision, based on an alternative analysis sha1l be included. 
The decision maker(s) has the authority and responsibility to provide a clear decision. If the decision cannot be made within the required time, an interim decision may be accepted with a closure date on the final decision. The decision maker(s) shall provide the reason for not reaching the final decision and support additional work required for that decision. There must always be a closure date based upon the priority.

The ad hoc team shall attempt to resolve conflicts, discontinuities, or omissions within 60 days or at a minimum, develop an acceptable set of planning assumptions for the integrated baseline. To transform an issue and the associated planning assumption to a valid requirement, the ad hoc team should consider the management, technical, cost, schedule, and mission risks and their likelihood of occurrence in determining the course of action.

The course of action and schedule determined by the ad hoc team shall be reported to the SWSEIG and updated for tracking purposes. When an action plan is completed to resolve an issue, the results shall be reported to the SWSEIG and appropriate baseline change requests prepared. include:

The general types of decision-making processes and documentation in RL

a) Manager or Deputy Manager decisions made within authority limits.

b) Assistant Managers or direct reports to the Manager including: Project and Service Manager decisions made within authority limits.

c) Memorandums, letters, or policies documenting a decision made that are sent through concurrence to the appropriate authority for signature.

d) Contract decisions including baseline changes documented through a concurrence chain to the appropriate authority for signature.

e) Agreements and decisions made between Assistant Managers or other direct reports to the Manager on issues within the individual or collective authorities.

f) Decisions made or recommended to a higher authority by RL SMB.

If a decision is made that affects the HSTB including technical baselines with associated schedule information, requirements, planning assumptions, budgets, cost estimates, interface requirements, performance specifications, regulatory requirements, or other significant items it can be brought to the RL SMB for reconsideration if a member of the SMB sponsors the reconsideration item for the agenda. The proponents of the reconsideration shall provide sufficient facts, analysis, and justification for the reconsideration discussion.

3.5.2.8 Implement Decision. The champion and owner are responsible to implement the decision and to communicate it with all of the affected organizations. 


$$
\text { WHC-SD-WM-SEMP-004 Rev. } 0
$$

3.5.2.9 Plan Required Analyses. If the decision maker(s) cannot reach a decision and request additional analyses, the assigned organization (champion) needs to prepare a plan for timely completion of the required work. The decision maker(s) must approve additional work and support it through a change in workscope.

3.5.2.10 Prepare Change Request. Based upon the priority of the required decision, the organization assigned to perform additional analyses wi1l prepare a change request and communicate it to the other affected organizations.

\subsubsection{Definitions}

- Issue

It is an obstacle that prevents a project from achieving its goals. An example of an issue is the lack of decision at any stage of the project cycle.

- Champion

A person who is assigned the responsibility to obtain resolution of an issue from the Project that is affected the most from the issue. This person has the responsibility to define, prioritize, and evaluate alternatives for resolving the issue.

- $\underline{\text { owner }}$

Person who has the authority to make a decision for the resolution of an issue.

\subsection{SITEWIDE SYSTEMS ENGINEERING INTEGRATION GROUP}

The SWSEIG is the overall steering group for the site systems engineering effort. Its activities are described in Section 2.5 of RLID 430.1 .

Membership consists of DOE and contractor representatives of the Hanford Projects and contractors. The SWSEIG meets weekly and serves as the principal forum for obtaining project support and actions for specific items evolving from sitewide systems engineering activities. As necessary, ad hoc teams are formed to address required actions as agreed to by the SWSEIG membership.

\subsection{PERFORMANCE LOGIC AND . SCHEDULE}

The logic for FY 1996 activities to develop and implement the products described above is shown in Figure 5 . Figure 6 is the associated schedule to implement the logic. RL receives a weekty status of these activities. 
Figure 5. FY 1996 Site Technical Integration Logic.

Develop site Speciflcation

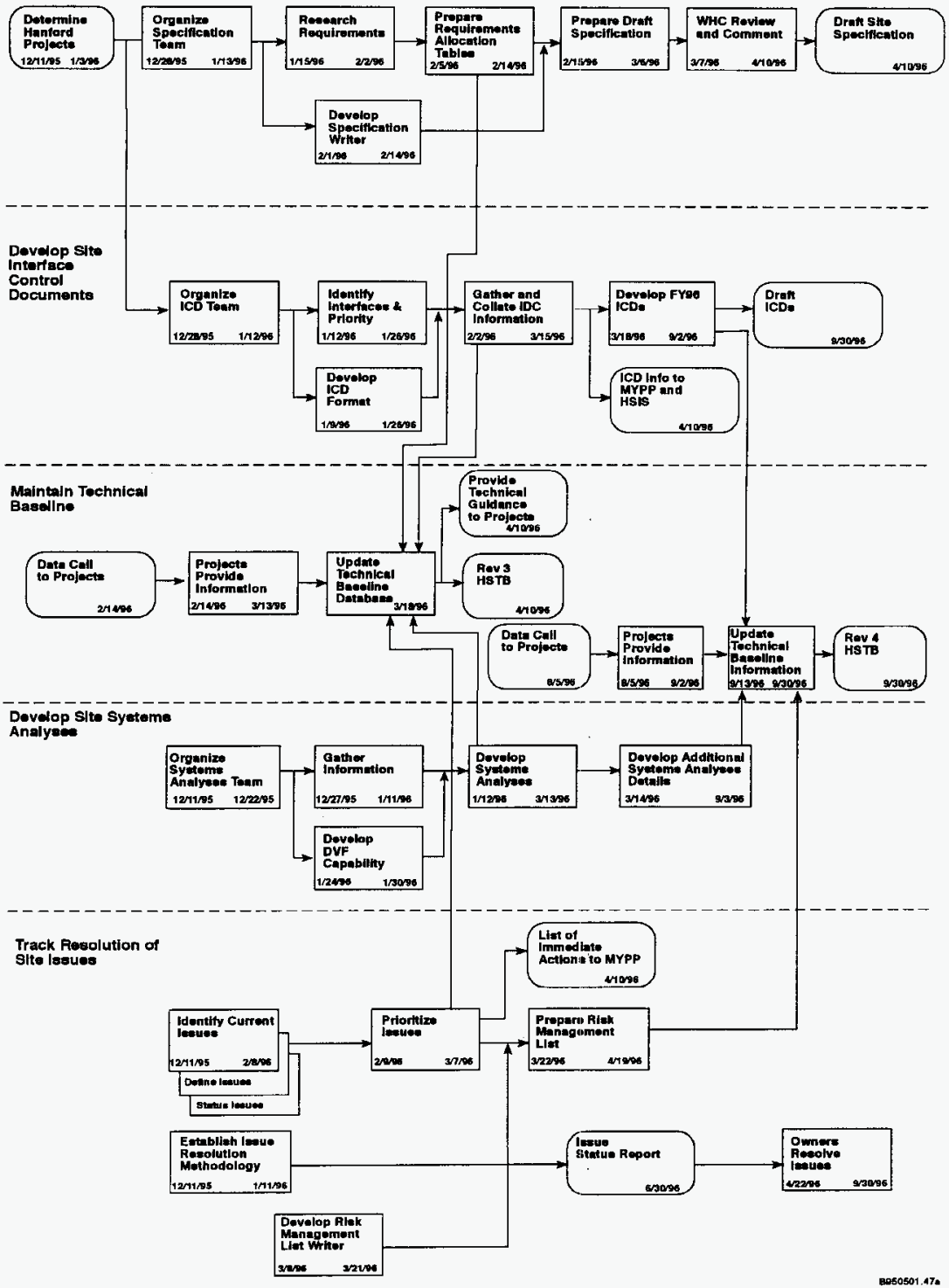


Figure 6. Develop Site Specification.

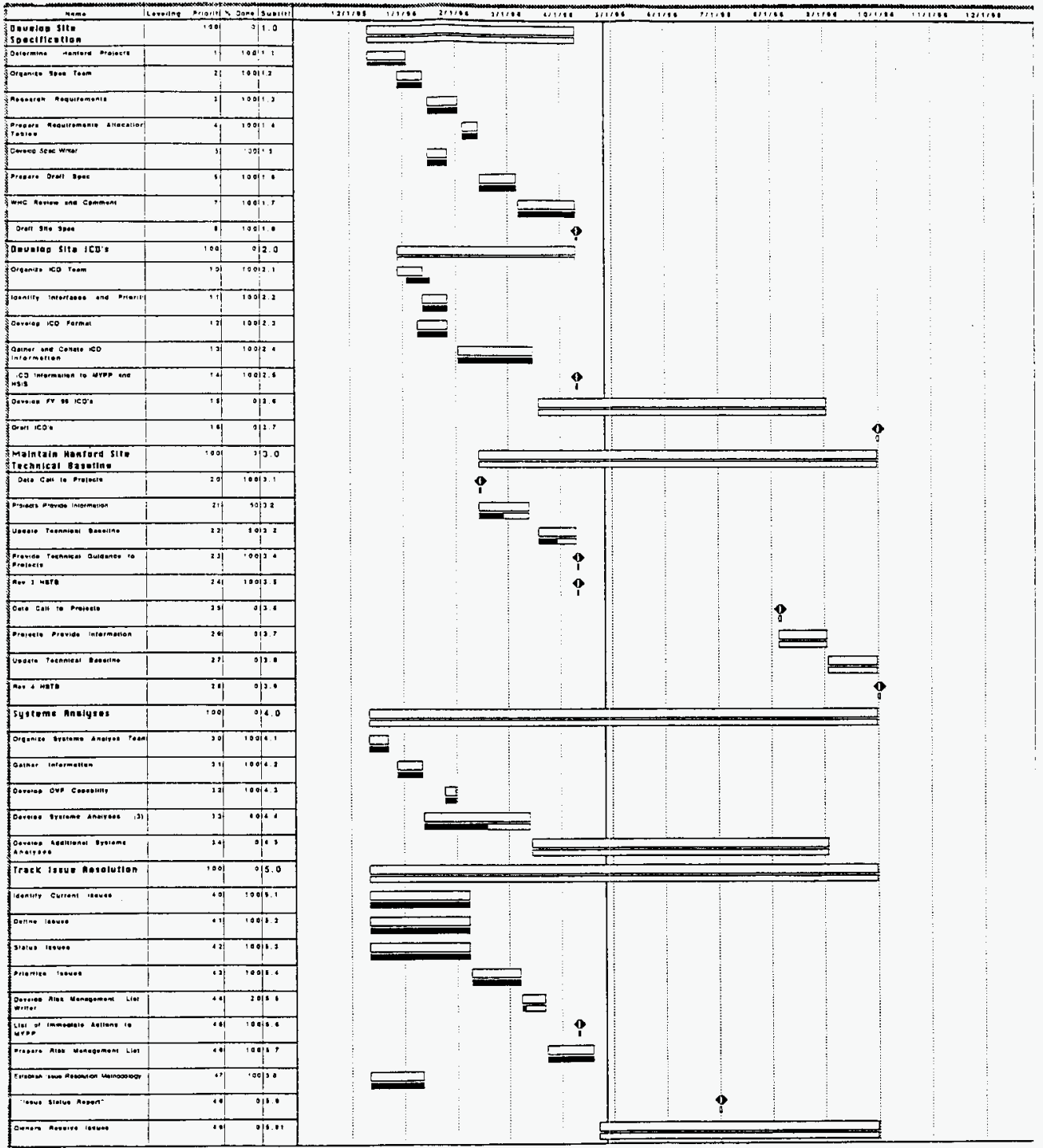


WHC-SD-WM-SEMP-004 Rev. 0

\subsection{INTEGRATION OF HSTB WITH THE MYPP PROCESS}

\subsection{INTRODUCTION}

In order for the information developed by the site systems engineering activities to be useful it is to be integrated with the annual financial planning process as technical input to the MYPP. This integration process is shown in Figure 7 . The HSTB is the source for site level technical baseline information. It has the potential to be used to support the numerous reporting requirements as shown in Figure 7 (e.g., RDS, BEMR). It forms the basis for the project level technical baselines which will contain the technical data relevant to each individual project. These technical baselines will be revised and maintained by making changes to the HSTB from which they are derived. In addition the quantitative data contained in these project technical baselines will be the bases for the technical content of the MOUs and ICDs described in Section 3.3. The technical content of this information is described in Section 5.2 below.

\subsection{TECHNICAL BASELINE}

The technical baseline describes the work to be accomplished and the technical standards that govern the work. The HSTB will be used to provide the following information in the Project Technical Baseline section of the MYPP: 1) Project Mission, 2) Project Technical Objectives, 3) Summary Level Forecasting Data (waste type, nuclear material, facility and infrastructure needs), 4) Drivers (key mission and regulatory), 5) Project Life-Cycle Requirements, and 6) Project Issues and Assumptions.

\subsubsection{Project Mission}

This section contains a narrative description of the end result(s) or end state that the Project will achieve, supported by the primary project responsibilities. It reflects the Projects' contribution to DOE's mission at the Hanford Site, as described in the Mission Direction Document (MDD) and the Hanford Site Cleanup Specification, as well as including relations to other Projects, as described in the ICDs. This forms the basis for defining intermediate products and sequence of events to achieve desired results. Where the final conditions are not completely developed or understood, specific activities are identified that will be accomplished to define these final conditions.

\subsubsection{Project Technical Objectives}

Each MYPP will ensure that the specific goals and strategies of the Hanford Site Project (HSP) and MDD, supporting the basis for existence of the Project, are clearly linked to the Project objectives and performance measures. 


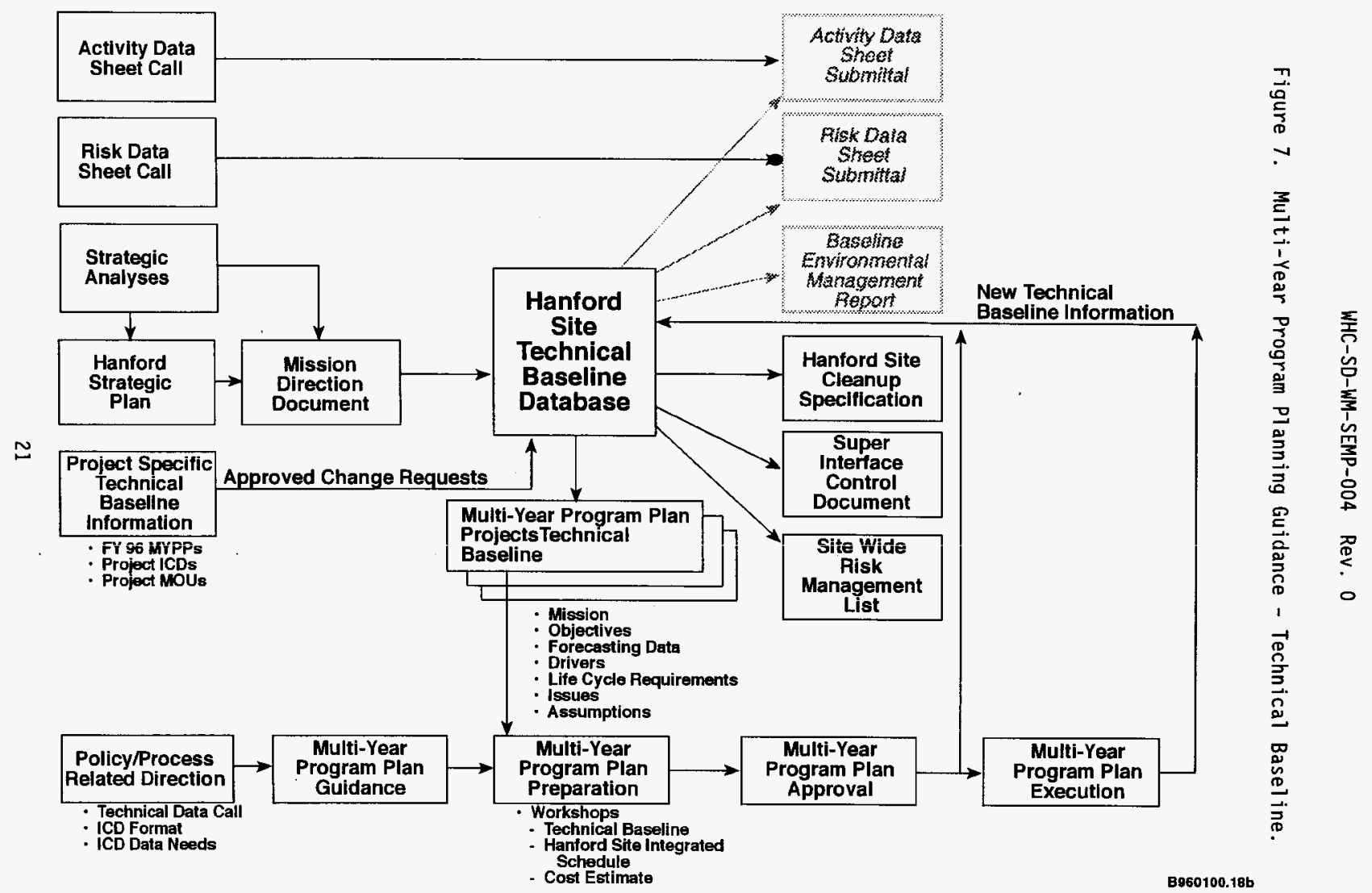


The significant goals, end points, or conditions to be achieved in accomplishing the Project mission shall be identified. This shall include general and specific objectives, deliverables, or activities that are essential to the Project mission. This will provide an overview of the activities and deliverables that are contained in project schedules. If the project objectives are not clear, then the MYPP technical logic, supporting schedules, and cost estimate sha11 include activities that lay out a plan for definition of the end objectives and requirements.

\subsubsection{Forecasting Data}

The Project inputs and outputs (wastes and nuclear materials) shall be identified and described on Stream Information Sheets. The Project facilities will be tracked via Facility Information Sheets and the Project infrastructure needs will be identified and described on Infrastructure Needs Sheets.

Each Information Sheet shall be completed for the entire 1ife-cycle of each facility and project by the HSP MYPP point-of-contact.

\subsubsection{Waste Type Data (Solid Waste, Tank Wastee, Liquid Effluents, Special} Case Waste). Waste inventory and volume projection data are an integral part of the technical basis for the planning, scheduling, and budgeting process. The scheduling and budgeting of work for a project must reflect the plans for disposition of waste. The DOE, stakeholders, and general public expect waste disposition information to be contained in DOE reports.

The waste type data is used to track the waste through generation, transfer, receipt, storage, and disposition in an efficient and cost effective manner. The following objectives support this goal:

- Identify all waste inventories onsite, Each source of existing waste within a project shall report activities separately.

All existing waste sources within a project need to be inventoried for future tracking, even though no near-term activities are planned for processing a waste source.

- Quantify the volume of waste,

- Prepare annual plans for waste disposition,

- Document the chain of custody for waste types between projects,

- Develop methods in using waste data to validate the basis for project and project planning,

- Improve the integration of data between projects,

- Enhance waste data reporting format. 
This information will be used to track the transfer and disposition of waste between, not within projects, with the exception of the Tank Waste Remediation System (TWRS) Project (single and double-shell tanks), which report waste separately.

5.2.3.2 Nuclear Materials (Special Nuclear Materials, Nuclear Fuel, Cesium capsules, Strontium capsules). Nuclear materials inventory and volume projection data are an integral part of the technical basis for the planning, scheduling, and budgeting process. The scheduling and budgeting of work for a project must reflect the plans for disposition of nuclear materials.

The nuclear materials data is used to track the nuclear materials through transfer, receipt, storage, and disposition in an efficient and cost effective manner. The following objectives support this goal:

- Identify a11 nuclear materials inventories onsite,

- Each source of existing nuclear materials within a project shall report activities separately.

- All existing nuclear materials sources within a project need to be inventoried for future tracking, even though no nearterm activities are planned for processing a nuclear materials source.

- Quantify the volume of nuclear materials,

- Prepare annual plans for nuclear materials disposition,

- Document the chain of custody for nuclear materials between projects,

- Develop methods in using nuclear materials data to validate the basis for project and project planning,

- Improve the integration of data between projects,

- Enhance nuclear materials data reporting format.

This information will be used to track the transfer and disposition of nuclear materials between, not within projects.

5.2.3.3 Facilities (Excess and Deactivated). Facility deactivation, decontamination and decommissioning, and closure are an integral part of the technical basis for the planning, scheduling, and budgeting process. The scheduling and budgeting of work for a project must reflect the plans for disposition of excess and deactivated facilities. The schedule for each facility shall include the key events. When a facility transitions through its life-cycle (e.g., when the facility begins operations, when the facility is declared excess, when the facility is deactivated, when the facility is decontaminated and decommissioned, and when the facility is closed). 
The facility data is used to track the facility through acquisition, operations and maintenance, deactivation, decontamination and decommissioning, and closure in an efficient and cost effective manner. The following objectives support this goal:

- Identify major facilities within each Project.

- Prepare annual plans for facility disposition.

- Document the chain-of-custody for each facility between projects.

- Develop methods in using facility data to validate the basis for project and project planning.

- Improve the integration of data between projects.

- Enhance facility data reporting format.

5.2.3.4 Infrastructure (e.g., Power, Steam, Water, Roads, Railroad, Sanitary Waste). Another forecasting goal is to ensure adequate infrastructure is in place to support the Projects' cleanup missions. Each project shall identify the services (infrastructure) that are necessary to achieve the project mission.

\subsubsection{Drivers}

The mission objectives and regulations that drive the Project shall be identified. These shall include Key and Regulatory Drivers.

5.2.4.1 Key Drivers. The Project Mission Objectives shall be derived from and linked to key documents (e.g., MDD) and the key documents shall be listed in the MYPPs.

5.2.4.2 Regulatory Drivers. The primary regulations that govern execution of the Project Mission shall be identified.

\subsubsection{Project Life-Cycle Requirements}

Requirements shall be identified and assigned for each Project Iifecycle phase. In addition general management requirements shall be identified.

5.2.5.1 Management Requirements. Management requirements are generally key dates, Project performance milestones, and interface definitions. They may include technology needs. This gives the Project an area to identify requirements for future technology that is necessary to meet the project's mission, goals, and objectives. If technology needs are identified, ensure that there is a clear linkage of these needs with programmatic technical baseline products or requirements.

5.2.5.2 Acquisition Requirements. Requirements that must be met during the acquisition phase sha11 be identified (e.g., Environmental Impact Statements, Resource Conservation and Recovery Act of 1976 [RCRA] Permits). 
5.2.5.3 Operations Requirements. The requirements that must be satisfied by the Projects during the operations phase shall be identified (e.g., retrieve, treat, store, and dispose of $X \mathrm{~m}^{3}$ of waste).

5.2.5.4 Maintenance Requirements. The maintenance requirements shall be identified, including availability and maintainability requirements.

5.2.5.5 Deactivation Requirements. Requirements that must be satisfied during the deactivation phase shall be identified (e.g., essential safety systems must be identified and maintained operational).

5.2.5.6 Decontamination and Deactivation Requirements. Requirements that must be satisfied during the decontamination and deactivation phase shall be identified (e.g., all radionuclides must be removed or stabilized).

\subsubsection{Project Issues and Assumptions}

The issues that must be resolved by the Projects shall be identified. These include Project-specific issues, as well as the Site level issues that have been assigned to the Project for resolution.

The assumptions that are used as a basis for the development of Objectives, Technical Requirements, Project Logic, Project Schedule, and Cost Estimates shall be documented. Identify key assumptions that have been agreed to with RL and are currently in place for project planning. All assumptions shall be traceable to a specific requirement or issue. The MDD, Hanford Site Cleanup Specification, and ICDs shall be the starting point for planning assumptions. The assumptions described in the MYPP shall include those contained in the MDD, Site Specification, and the ICDs in addition to more detailed assumptions. 
WHC-SD-WM-SEMP-004 Rev. 0

APPENDIX A

RLPD 430.1

HANFORD SITE SYSTEMS ENGINEEERING POLICY

A-1 
WHC-SD-WM-SEMP-004 Rev. 0

\begin{tabular}{|l|ll||}
\hline \multicolumn{3}{|l||}{$\begin{array}{l}\text { Department of Energy } \\
\text { Richland Operations Office }\end{array}$} \\
\hline TITLE: HANFORD SITE SYSTEMS ENGINEERING POLICY & $\begin{array}{l}\text { Number: } \\
\text { Effective Date: } \\
\text { Prepared by: } \\
\text { Page: }\end{array}$ & $\begin{array}{l}\text { RLPD } 430.1 \\
\text { PMD } \\
\text { PMD }\end{array}$ \\
\hline
\end{tabular}




\subsection{PURPOSE}

This directive establishes the policies for the application of systems engineering principles in defining and controlling the technical basis for accomplishing Hanford Work. This includes top-level technical definition and technical integration of project/services work for the Environmental Management mission conducted at the Hanford Site.

\subsection{APPLICABILITY}

This policy applies to all Hanford project and service workscopes and contractors involved in the site cleanup, environmental remediation, environmental restoration, facility deactivation, waste management activities, and sitewide services requiring facilities and physical infrastructure. This policy applies across the entire project/service life cycle (i.e. design, construction, test, operation and decommissioning). For PNNL, the policy applies to PNNL cleanup projects and the infrastructure/landlord services necessary to support PNNL.

\subsection{POLICY}

Systems engineering principles shall be used at the mission level and, as appropriate, at the project/services level such that the technical basis for work is defensible, traceable and controlled. The overview for this approach as shown in Figure 1 will:

- Provide a high level technical baseline and associated schedule information with consistent traceability from the strategic plan to the projects/services.

- Establish an iterative process to achieve a consistent top down set of integrated technical documents for site management purposes.

- Produce useable results and products that support site-wide technical integration and physical systems management.

- Bound the extent and scope of the sitewide systems engineering activity to: define and manage requirements, issues and assumptions, interface control between projects and infrastructure, waste stream data, and provide a high level technically sound baseline for Project Hanford:

- Require projects to continue the application of systems engineering principles to the extent required. 
WHC-SD-WM-SEMP-004 Rev. 0

\begin{tabular}{|l|ll||}
\hline \multicolumn{3}{|l||}{$\begin{array}{l}\text { Department of Energy } \\
\text { Richland Operations office }\end{array}$} \\
\hline TITLE: HANFORD SITE SYSTEMS ENGINEERING POLICY & $\begin{array}{l}\text { Number: } \\
\text { Effective Date: } \\
\text { Prepared by: } \\
\text { Page: }\end{array}$ & $\begin{array}{l}\text { RLPD } 430.1 \\
\text { PMD }\end{array}$ \\
\hline
\end{tabular}


- Establish, operate and maintain a Sitewide Systems Engineering Integration Group (SWSEIG) which will assist in identifying the data set and attributes used by sitewide systems engineering (SWSE), identification of impacts and issues, and interface management between major site projects.

- Establish a process to identify, prioritize and facilitate the resolution of major sitewide issues to assure accomplishment of the Hanford clean-up mission.

Additional information on implementation of this policy can be found in the RLID 430.1 Systems Engineering Criteria and Document Implementing Directive.

\subsection{REFERENCES}

1. DOE/RL-96-15 Hanford Management Plan, February 1996.

2. DOE Order 430.1, Life Cycle Asset Management Guide 10., Project Execution and Management Planning

\subsection{RESPONSIBILITIES}

Project/Services DOE and Contractor responsibilities (AMF, AMW, TWRS, AMT, AME, ESH):

- Participates on SWSEIG with RL and contractor members. (DOE and Contractor)

- Participate in development of necessary and sufficient minimum data requirements for the site technical specification and interface management (i.e Integrated Site Technical Baseline Document). (DOE and Contractor)

- Provide updates, continuously at the time baseline data is revised, to the required Sitewide Technical database. (Contractor)

- Assume management and resource responsibility for the resolution of identified SWSE issues. (DOE)

- Provide documentation for and perform project/service systems engineering at the level of detail appropriate for the dollar value of the project, complexity, sensitivity to changes, and impacts on other projects or services using DOE Order 430. 1 on Life Cycle Asset Management and its Management Guides for guidance. (Contractor)

- Perform all detailed project/service analysis, all trade studies,all SWSE issue analysis, and initial change management of SWSE data. (Contractor)

- Assist in analysis of SWSE data for issues. (DOE and Contractor) 
WHC-SD-WM-SEMP-004 Rev. 0

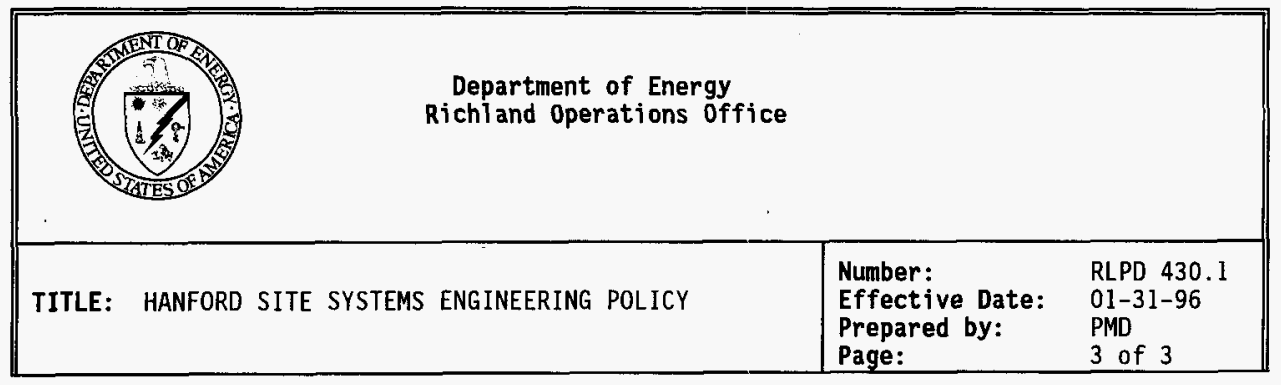


Site Management Board (SMB):

- Provide decisions requested on cross-cutting significant issues identified through SWSE that cannot be resolved by individual projects/services.

CF0/PID Responsibilities:

- Manage Hanford Strategic Planning process. (Hanford Strategic Plan, Mission Direction Document)

- Manage Site Baseline process.

- Manage Sitewide Change Control process.

- Manage site baseline planning and integration process and conduct analyses of sitewide data.

- Assist SWSE process

Sitewide Systems Engineering (AMF/PMD) Responsibilities:

- Manage Sitewide Systems Engineering Database (SWSEDB) process.

- Manage SWSE interface control process.

- Manage SWSE issue resolution process.

- Manage SWSE Integration Group.

- Assist in analyses of SWSE data for issues. 
WHC-SD-WM-SEMP-004 Rev. 0

RLID 430.1

SYSTEMS ENGINEERING CRITERIA DOCUMENT AND IMPLEMENTING DIRECTIVE 
WHC-SD-WM-SEMP-004 Rev. 0

\begin{tabular}{|ll|ll|}
\hline \multicolumn{3}{|l|}{$\begin{array}{l}\text { Department of Energy } \\
\text { Richland Operations office }\end{array}$} & \\
\hline & & \\
\hline
\end{tabular}




\subsection{PURPOSE}

This RLID and associated attachments provides implementing direction for the Systems Engineering process at Hanford.

\subsection{CANCELLATION}

None.

\subsection{APPLICABILITY}

This direction applies to all Hanford project and service workscopes and contractors involved in the site cleanup, environmental remediation, environmental restoration, facility deactivation, waste management activities, and sitewide services requiring facilities and physical infrastructure. This directive applies across the entire project/service life cycle (i.e. design, construction, test, operation and decommissioning). For PNNL, the policy applies to PNNL cleanup projects and the infrastructure/landlord services necessary to support PNNL.

\subsection{REFERENCES}

See Attachment A, Section 1.1 for reference information.

\subsection{DEFINITIONS}

\subsection{ACRONYMS}

A11 applicable acronyms are defined, as necessary, within the attached documents

\subsection{DEFINITION OF TERMS}

All terms and definitions are either obvious from context or given specifically with in the attachments provided.

\subsection{RESPONSIBILITIES}

All roles and responsibilities are discussed in Section 2.0 of Attachment A. 
WHC-SD-WM-SEMP-004 Rev. 0

\begin{tabular}{|ll|ll|}
\hline \multicolumn{3}{|l|}{$\begin{array}{l}\text { Department of Energy } \\
\text { Richland Operations office }\end{array}$} & \\
\hline & & \\
\hline
\end{tabular}




\subsection{GENERAL CONTENT}

A description of specific criteria and implementing requirements are provided in the attachments.

\subsection{ATTACHMENTS}

The following Attachments to this RLID provide implementing direction for the details associated with further definition and implementation of Systems Engineering Program a Hanford.
A - Attachment - Systems Engineering Criteria and Implementation Plan (11 pages, 4 Figures)
B - Attachment - Sitewide Systems Engineering Risk Management Plan (2 pages)
C - Attachment - Sitewide Systems Engineering Decision Management PIan (1 page)
D - Attachment - Sitewide Systems Engineering Information Management Plan (1 page) 


$$
\text { WHC-SD-WM-SEMP-004 Rev. } 0
$$

\section{ATTACHMENT A \\ SYSTEMS ENGINEERING CRITERIA AND IMPLEMENTATION PLAN \\ TABLE OF CONTENTS}

\subsection{PRINCIPLES AND IMPLEMENTATION}

1.1 BACKGROUND INFORMATION

1.2 SYSTEMS ENGINEERING PRINCIPLES AT HANFORD

1.3 IMPLEMENTATION

\subsection{SITEWIDE SYSTEMS ENGINEERING MANAGEMENT}

2.1 ORGANIZATIONAL STRUCTURE

2.2 OVERALL SYSTEMS ENGINEERING GOALS AND OBJECTIVES

2.3 SITEWIDE TECHNICAL INTEGRATION FRAMEWORK, DOCUMENT HIERARCHY, AND PROCESS

2.3.1 ROLES AND RESPONSIBILITIES

2.3.2 INTEGRATION APPROACH

2.3.3 DOCUMENT HIERARCHY

2.3.4 HANFORD SYSTEMS ENGINEERING PROCESS

2.4 MAJOR DELIVERABLES

2.4.1 SITE TECHNICAL BASELINE

2.4.1.1 SITE TECHNICAL SPECIFICATION

2.4.2.1 SITE INTERFACE CONTROL DOCUMENTS

2.4.2 ISSUE IDENTIFICATION, TRACKING AND RESOLUTION

2.5 SITEWIDE SYSTEMS ENGINEERING INTEGRATION GROUP

2.5.1 SWSEIG CHARTER

2.5.2 SWSEIG MEMBERSHIP

2.5.3 SWSEIG ROLES AND RESPONSIBILITIES

3.0 REPORTING REQUIREMENTS

\section{FIGURES:}

Figure 1: $\quad$ Sitewide Systems Engineering Framework

Figure 2: $\quad$ Sitewide Systems Engineering Technical Document Hierarchy

Figure 3: $\quad$ Sitewide Systems Engineering Process Document Hierarchy

Figure 4: Hanford Systems Engineering (SE) Process 
WHC-SD-WM-SEMP-004 Rev. 0

\subsection{PRINCIPLES AND IMPLEMENTATION}

\subsection{BACKGROUND INFORMATION}

RL Hanford Site Management recognizes the need to integrate the technical workscope for the Hanford Project. The application of systems engineering principles is essential to plan and prioritize the site activities and cleanup schedule. The principles provide a technical management tool to influence and define requirements for all programs and projects. The identification and resolution of major issues through the application of systems engineering principles can significantly influence the Hanford Strategic Plan and the individual projects. In general, integrated work can be accomplished more effectively and with more confidence when the correct scope is being addressed.

In 1992 the Defense Nuclear Facilities Safety Board (DNFSB) issued Recommendation 92-4 to the Secretary of Energy. DNFSB 92-4 addressed concerns regarding the technical integration activities for the Tank Waste Retrieval System and recommended that DOE employ "systems engineering" to resolve these problems.

In response to 92-4, RL committed for sitewide systems engineering to provide a management $\mathrm{pl}$ an and implementation $\mathrm{plan}$, including specific deliverables, which would describe the actions to be taken at the site level to manage technical workscope definition, and integration. This criteria and implementation plan, and the associated policy statement, fulfill that commitment.

Additional background documents and guidelines for "sitewide systems engineering" are contained in several general references.

While these references address, in broad terms, the use of "systems engineering" in the planning and execution of the Hanford Mission, they contain no detailed specific requirements or specifically defined "systems engineering" methodology. These major guidance documents are:

- DOE-HQ: DOE Order 430.1, Life Cycle Asset Management Project Management Guide - 10 (no specific requirements, guide only)

- Tri-Party Agreement (TPA): General commitment to integration without specific details/mechanics.

- OMB: Recommends-use of systems engineering without specifics regarding methodology.

Because of the guidance and general nature of the currently available documentation on "systems engineering", RL. has adopted systems engineering methods and a process which is compatible with the current Hanford Management $\mathrm{Pl}$ an and the diverse nature of the different technical activities at Hanford. 
WHC-SD-WM-SEMP-004 Rev. 0

\subsection{SYSTEMS ENGINEERING PRINCIPLES AT HANFORD}

The fundamental principles for systems engineering activities at Hanford are captured in the following bullets:

- $\quad$ System engineering principles are not a substitute for good project management.

- Because of the diverse elements and complexity of the Hanford Project, the multitude of pre-existing physical systems, and preexisting agreements and processes driving project/services planning, textbook Systems Engineering processes will not be uniformly required or implemented across the entire site.

Sitewide Systems Engineering (SWSE) will define and manage requirements, issues, assumptions, and interfaces for sitewide activities requiring physical facilities and the boundary inputs/outputs requirements for projects. All operable units are considered physical facilities. It is a framework for the project/service systems engineering (see Fig. 1 - Framework).

- SWSE will be limited to the high level site technical baseline with nominally 500 or less major technical and associated schedule information for the site. SWSE data collection will not be done lower than the major project/service level where specific responsible Project Managers can be identified.

- Project/Service Systems Engineering will be done by the projects and services at the level of detail appropriate for the dollar value of the project, complexity, sensitivity to changes, and impact on other projects/services. Detailed analysis, all trade studies, and initial change management of SWSE data is done at the project/service level. DOE Order 430.1 on Life Cycle Asset Management and its management guides will be utilized as appropriate.

- System Engineering principles are a support system for development of the baseline work plans and budget submittals.

- $\quad$ System Engineering scope will be limited to the Environmental Management physical project work and overhead/services requiring physical facilities and infrastructure.

- At Pacific Northwest National Laboratory (PNNL) the required System Engineering scope will be limited to the Environmental Management Mission and the infrastructure/landlord services necessary to support other PNNL activities. 


\section{WHC-SD-WM-SEMP-004 Rev. 0}

- System Engineering applications are not:

- A project management system for cost and schedule.

- A budget system: budget issues/priorities/schedules are a separate area for projects/services and the RL Budget Division.

- A technology needs and development system: at Hanford that function is performed by the Site Technology Coordination Group (STCG).

- A detailed composite total site systems engineering network is not required. A sitewide systems engineering database will be developed for the site level system description and maintained by SWSE. The principle vehicle for coordination of this information will be the Sitewide Systems Engineering Integration Group (SWSEIG). Key physical interfaces between projects and services will be identified through SWSE.

- Projects/Services are not required to use the same software or level of detail in their application of SE. Projects and services are required to be able to interface electronically with the SWSE data base for the transfer and revision of data. Projects and services can implement the systems engineering principles and criteria as needed to get the results desired for the project/service and the information required for site level systems engineering.

- Projects/services will perform single and multi-area trade studies, analysis of cost savings, contingency analysis, single and multi-area vulnerability analysis, and issue resolution, as required.

- The sitewide systems engineering data will be updated continuously through the change management process in developing the work $\mathrm{plan}$, budgets, funding changes, and evaluations. Hard copies, if required, will be published periodically.

\subsection{IMPLEMENTATION}

The issuance of the Hanford Systems Engineering Policy and Implementing Directives relects the elements approved by DOE-RL Site Management Board on December 11, 1995, and formally implements these requirements. 
WHC-SD-WM-SEMP-004 Rev. 0

\subsection{SYSTEMS ENGINEERING MANAGEMENT}

\subsection{ORGANIZATIONAL STRUCTURE}

The Hanford organizations involved in SWSE, technical integration and systems management include the following entities:

- DOE-RL Lead Organization for SWSE: AMF/PMD

- DOE-RL Lead Organization for Integration: CFO/PID

- Contractor Lead Organization: WHC Site Integration Group

- DOE-RL Projects/Programs: AMT, AMW, AME, AMF, ESH, TWRS

- Contractor Projects/Programs: As required to support and perform the DOE Projects/Programs involvements and systems engineering efforts.

Further details on roles and responsibilities is given in Section 2.3.

\subsection{OVERALL SYSTEMS ENGINEERING GOALS AND OBJECTIVES}

The overall Goals and objectives of the systems engineering effort are as follows:

- Produce a Hanford Site Technical Baseline that provides a consistent traceable linkage connecting strategic level documents to the project baseline documents. An iterative process will be used (i.e. bottom-up, top-down, issue identification).

- Produce SWSE products and resuTts that are useable and support projects and sitewide services. Major products and deliverables are given on Section 2.4.

- Define and manage, at the SWSE Level:

* Requirements

* Issues and assumptions

* Interfaces Control between Projects, Infrastructure

* Waste Stream Data tracked to the intra-project level

- Projects/services utilizing systems engineering principles as necessary to develop meaningful, integrated baseline work plans. 
WHC-SD-WM-SEMP-004 Rev. 0

\subsection{SITEWIDE TECHNICAL INTEGRATION FRAMEWORK, DOCUMENT HIERARCHY, AND PROCESS}

\subsubsection{ROLES AND RESPONSIBILITIES}

Project/Services DOE and Contractor Responsibilities (AMF, AMW, TWRS, AMT, AME, ESH):

- Participates on SWSEIG with RL and contractor members. (DOE and Contractors)

- Participate in development of necessary and sufficient minimum data requirements for the site technical specification and interface management (i.e Integrated Site Technical Baseline Document). (DOE and Contractors)

- Provide updates, continuously at the time baseline data is revised, to the required Sitewide Technical database. (Contractor)

- Assume management and resource responsibility for the resolution of identified SWSE issues. (DOE)

- Provide documentation for and perform project/service systems engineering at the level of detail appropriate for the dollar value of the project complexity, sensitivity to changes, and impacts on other projects or services using DOE Order 430.1 on life Cycle Asset Management and its Management Guides for guidance. (Contractor)

- Perform all detailed project/service analysis, all trade studies, all SWSE issue analysis, and initial change management of SWSE data. (Contractor)

- Assist in analysis of SWSE data for issues. (DOE and Contractor)

CF0/PID Responsibilities:

- Manage Hanford Strategic Planning process. (Hanford Strategic Plan, Mission Direction Document)

- Manage Site Baseline process.

- Manage Sitewide Change Control process.

- Manage site baseline planning and integration process and conduct analyses of sitewide data. 
WHC-SD-WM-SEMP-004 Rev. 0

- Assist SWSE process.

Sitewide Systems Engineering (AMF/PMD) Responsibilities:

- Manage Sitewide Systems Engineering Database (SWSEDB) process.

- Manage SWSE interface control process.

- Manage SWSE issue resolution process.

- Manage SWSE Integration Group.

- Assist in analysis of SWSE data for issues.

Site Management Board (SMB):

- Provide decisions requested on cross-cutting or significant issues identified through SWSE that cannot be resolved in accordance with the SWSE Decision Management Plan in Attachment C of RLID 430.1 .

\subsubsection{INTEGRATION APPROACH}

The Hanford Systems Engineering/Technical Integration Process is a combined effort where sitewide support and line organizations function as a team to achieve the site objectives. The Sitewide Systems Engineering (SWSE) functions managed by AMF/PMD and the CFO/PID group provide analysis of the sitewide data and are service organizations to the Site Integrator or line customers. The SWSE and PID efforts will not assume line authority or responsibility for the application of system engineering principles at the program/project level. SWSE and PID will provide the "4-Cs": coordination, consolidation, consistency, and consultation.

The framework model for the SWSE activities at Hanford is reflected in Figure 1.

The SWSE work at RL will focus on capturing and managing the boundary requirements for sitewide services and the boundary input/output requirements and assumptions for projects/services. Detailed Systems Engineering will be done by the projects/services at the level of detail appropriate for the work, complexity, sensitivity to changes and impact on other projects/services (graded approach). Detailed analysis, trade studies, and initial change management is done at the project/service level. 


\subsubsection{DOCUMENT HIERARCHY}

The Hanford technical document hierarchy is given in Figure 2. The key technical products of the sitewide technical integration effort are the Site Technical Baseline and the site Technical Issues Management list. The SWSE process document hierarchy is given in Figure 3.

\subsubsection{HANFORD SYSTEMS ENGINEERING PROCESS}

The Hanford Site Systems Engineering Process is summarized as follows (see Figure 4):

- The minimum practical data elements and definitions for the SWSE effort is determined and revised as needed.

- Specific physical performance requirements are noted at the sitewide and the project/service level. Each project/service defines its additional requirements through its own tailored SE or equivalent process. These requirements might include sitewide services, design, construction, start-up/test and/or operational (e.g. S/RID), and decommissioning/stabilization, decontamination, and demolition requirements.

- The projects/services, in performing their $p 1$ anning process which includes systems engineering principles, develop the raw data required for SWSE.

- SWSE consolidates the data and includes appropriate site level physical performance requirments and interface data and sends information back to the projects/services and to PID for analysis.

- The information is analyzed by the projects/services to verify the planning basis and by SWSE and PID for consistency of assumptions and baseline information. Cost savings opportunities and technical issues are identified.

- In a risk management/issues resolution process, SWSE and major project/service issues are identified. Then a lead project/service and impacted parties are identified for an ad hoc i.ssue resolution team. The issues are resolved through agreed planning assumptions or analysis to determine appropriate requirements.

- In a decision management process issues are resolved and the confirmed SWSE data is provided to SWSE and PID. 
- In an iterative process, the projects/services resolve issues and revise the SWSE data as needed. In any cycle when the issues are resolved through analysis or adoption of an acceptable set of assumptions, sitewide integration has been achieved.

- As the projects/services continue with work execution they implement baseline change control, evaluations, and budget/funds management. Any changes to the SWSE outputs will be provided to SWSE and PID through the appropriate change control process as necessary.

- SWSE will continuously update the SWSE database and make it available in electronic form for review/etc.

Details of SWSE deliverables are given in Section 2.4.

\subsection{MAJOR DELIVERABLES}

\subsubsection{SITE TECHNICAL BASELINE}

The sitewide technical document hierarchy is shown in Figure 2 . Major deliverables are specifically addressed in the following text.

The Site Technical Baseline is a major product of the sitewide systems integration effort. The baseline includes the following:

- Site Technical Specification

- Site Interface Control Documents

Sitewide Systems Engineering Products

(A) Site Technical Specification

Consolidated Project/Services Physical Performance Requirements/Assumptions

* By project/service

* Specific physical performance requirements of site/project/services composite.

Technical Basel ine Elements

* High level typically less than 500 activities by WBS.

Schedule Information

* High level typically less than 500 activities by WBS. 
Consolidated Interface (Input/Output) Requirements

* By WBS to major sub-project level as identified by SWSE.

* Include points of contact for contractor and DOE for each sub-project and data element.

* Define data elements of input/output information to be gathered.

* Define Project/Service "manager" for each data element.

* Define characteristics of each data elements required at the minimum practical level for the user of the data.

- Could be yes/no without quantification.

- Could be only projected change from existing levels.

- Could be actual quantities and future quantities.

- Could be categories such as type of waste, type of analytical test.

- Waste stream data elements should include disposition path even if internal to the sub-project.

* Define appropriate future projections for planning estimate periods matched to economic life of asset/data element.

- Current need.

- 5 year and 20 year projections for infrastructure.

- Known future large needs like tank waste vitrification.

* Define quality of information for data element at source of need input.

- Actual real data.

- Design estimate.

- Knowledgeable guesstimate (SWAG).

* Report providing consolidated sitewide totals for needed data elements with sub-reports by data element showing needs by sub-project.

(B) SWSE Interface Control Documents

- Defines SWSE interfaces

- Defines Project/Service "manager" of interface

- Defines current status of interface

This information will comprise a integrated technical view of the site for site management purposes. The Site Technical Baseline will be controlled.

(C) Sitewide Issue Resolution Status Report

- Defines SWSE issues to be resolved

- Defines Project/Service with lead role to manage resolution of the issue 


\section{WHC-SD-WM-SEMP-004 Rev. 0}

- Defines schedule for resolution

\subsubsection{ISSUE IDENTIFICATION, TRACKING AND RESOLUTION}

A 1ist of SWSE major project technical issues will be assembled as part of the site technical integration and baseline preparation workscope.

The issues will be placed in a database and assigned to the responsible projects/services for resolution.

SWSE will track and report action plans and status on these SWSE and major technical issues. The DOE-RL Site Management Board will be updated on a routine basis. 
WHC-SD-WM-SEMP-004 Rev. 0

\subsection{SITEWIDE SYSTEMS ENGINEERING INTEGRATION GROUP (SWSEIG)}

\subsubsection{SWSEIG CHARTER}

This team shall assist in identifying the SWSE data sets, detailed data attributes, major technical issues and impacts, and major interfaces between site projects/services.

\subsubsection{SWSEIG MEMBERSHIP}

This team will include key DOE-RL and Contractor participation from each of the following program/project entities:

- TWRS, Facility Transition, Spent Nuclear Fuel, Solid Waste, Liquid Waste, Liquid Effluent, Environmental Restoration, Site Infrastructure, Program Integration, ES\&H, Science \& Technology, Regulatory Analysis, and Analytical Services.

Changes to the agreed to membership, for whatever reasons, must be communicated to PMD in writing by the responsible RL Division Director.

\subsubsection{SWSEIG ROLES AND RESPONSIBILITIES}

DOE and Contractor Project/Service Responsibilities:

- Participate in SWSEIG.

- Serve as SWSE point of contact for Project and communicate SWSE information to appropriate project personnel including schedule and budget groups.

- Represent Project technical position(s).

- Provide input to the Site Technical Baseline database.

- Assist in definition of SWSE interface data set.

- Assist in identification of SWSE issues and determination of projects/systems impacted by resolution.

- Assist in identification of project/service with lead responsibility for issue resolution and items to be considered.

- Communicate and coordinate needed project/program response for issue resolution.

- Provide input and update data to establish and maintain SWSE data sets (site specification, ICD's, site issues).

SWSE Responsibilities: 


\section{WHC-SD-WM-SEMP-004 Rev. 0}

- Maintain SWSE data base (SWSEDB).

- Consolidate project/service input to the SWSEDB.

- Track resolution of SWSE and major project/service technical issues in database.

- Coordinate SWSEIG activities.

- Maintain data sets for SWSE Interface Control Documents (ICDs).

\subsection{REPORTING REQUIREMENTS}

AMF/PID will establish the types and frequency of reporting requirements for SWSE work. 


\author{
WHC-SD-WM-SEMP-004 Rev. 0
}

\title{
ATTACHMENT B \\ SITEWIDE SYSTEMS ENGINEERING \\ RISK MANAGEMENT PLAN
}

\subsection{RISK MANAGEMENT PLAN}

The risk management approach for SWSE is an issues management process for issues that have major impact beyond a major project or service. In general, the focus will be on resolving conflicts or discontinuities, omissions in project/service baselines, interface compatibilities, and conflicts in requirement/planning assumptions. The issue identification and resolution process will be used to transform planning assumptions with major impacts into defined requirements. A limited, select number of technical issues that are not cross-cutting may be reported on the Sitewide Issue Resolution Status Report. Typically, subordinate risks/issues will be identified and managed by the individual project/service as necessary. Significant or cross cutting issues that cannot be resolved at the project/service level should be elevated to the Site Management Board (SMB) for resolution.

\subsection{SWSE ISSUE IDENTIFICATION AND DEFINITION}

As SWSE data is developed and analyzed by projects/services, the SWSEIG, SWSE personnel, PID personnel, and others, potential issues for resolution may be identified. These may include issues impacting multiple projects/services or major single project/service issues. When identified, the extent and potential severity of consequences raised by the issue should be defined as well as the cross-cutting projects/services impacted. The SWSE group will determine if the issue is of significance enough to include in the tracking system at any level. The tracking system and Sitewide Issue Resolution Status Report may contain two levels of issues: the Critical Issues Management List, and the Issues Management List.

\subsection{ISSUE RESOLUTION TEAM ASSIGNMENT}

The SWSEIG group will make a preliminary assignment of a lead project/service and other affected projects/services to an ad hoc team for the resolution of the issue. Requests to change leadership or members of the ad hoc team will be made to the SWSE group.

\subsection{ISSUE RESOLUTION AND TRACKING}

The ad hoc team will determine a course of action and schedule to resolve the issue. The team shall attempt to resolve conflicts, discontinuities or omissions within 60 days or at a minimum, develop an acceptable set of planning assumptions for the integrated baseline. For an issue set up to transform a planning assumption to a valid requirement, the ad hoc team should consider the management, technical, cost, schedule, and mission risks and their likelihood of occurrence in determining the course of action. The course of action and schedule determined by the ad hoc team should be reported the SWSE group and 


\section{WHC-SD-WM-SEMP-004 Rev. 0}

updated for tracking purposes. When an action plan is completed to resolve an issue, the results should be reported to the SWSE group and appropriate baseline change control processes utilized as necessary. Issues are resolved using the RL decision management process. 
WHC-SD-WM-SEMP-004 Rev. 0

\section{ATTACHMENT B}

\subsection{SITEWIDE ISSUE STATUS REPORTING}

The Sitewide Issue Resolution Status Report will be maintained as an administratively controlled document by the SWSE group. It will be updated electronically by the SWSE group as additions, changes, or completed resolutions occur. Monthly it will be sent to the RL Site Management Board with significant changes or delinquencies noted.

Completed resolutions will be carried on the report until any required change control process is completed. 


\section{ATTACHMENT C \\ SITEWIDE SYSTEMS ENGINEERING \\ DECISION MANAGEMENT PLAN}

\subsection{DECISION MANAGEMENT APPROACH}

There are multiple routes to a decision in DOE-RL depending on the decision to be made and the appropriate decision making authority or authorities. The approach for SWSE related decisions is not to prescribe specific procedure making processes to be followed, but to recognize the existence of multiple valid paths and focus on the path to obtain a corporate review of a specific decision/issue where that review is supported by a member of the DOE-RL Site Management Board.

\subsection{DOE-RL DECISION MAKING PROCESSES AND DOCUMENTATION}

The general types of decision making processes and documentation in DOE-RL are:

a) Manager/Deputy Manager decisions made within authority limits.

b) Assistant Managers or direct reports to the Manager including: Project/Service Manager decisions made within authority limits.

c) Memorandums/Letters/Policies documenting a decision made that are sent through concurrence to the appropriate authority for signature.

d) Contract decisions including baseline changes documented through a concurrence chain to the appropriate authority for signature.

e) Agreements and decisions made between Assistant Managers and/or other direct reports to the Manager on issues within the individual or collective authorities.

f) Decisions made or recommended to a higher authority by the DOE-RL Site Management Board.

All of the above routes to a decision effecting SWSE items may be utilized.

\subsection{DOE-RL RECONSIDERATION OF DECISIONS}

If a decision is made that affects the SWSE database including technical baselines with associated schedule information, requirements/planning assumptions, budgets/costs, interface requirements, performance specifications, regulatory requirements or other significant items it can be brought to the DOE-RL Site Management Board (SMB) for reconsideration if a member of the SMB sponsors the reconsideration item for the agenda. The proponents of the reconsideration should provide 
WHC-SD-WM-SEMP-004 Rev. 0

sufficient facts, analysis, and justification for the reconsideration discussion. 


\section{ATTACHMENT D \\ SITEWIDE SYSTEMS ENGINEERING \\ INFORMATION MANAGEMENT PLAN}

\subsection{INFORMATION MANAGEMENT APPROACH}

The information management approach for SWSE is to provide maximum flexibility to the projects/services to define and implement information management systems but retain the ability to electronically transfer SWSE data and update the SWSE database.

\subsection{INFORMATION MANAGEMENT CRITERIA}

The following information management criteria are established for SWSE:

a) A detailed composite total site systems engineering network is not required.

b) Projects/Services are not required to use the same software or level of detail in their application of systems engineering principles.

c) Projects/Services are required to be able to interface electronically with the SWSE database for the transfer and revision of data. 


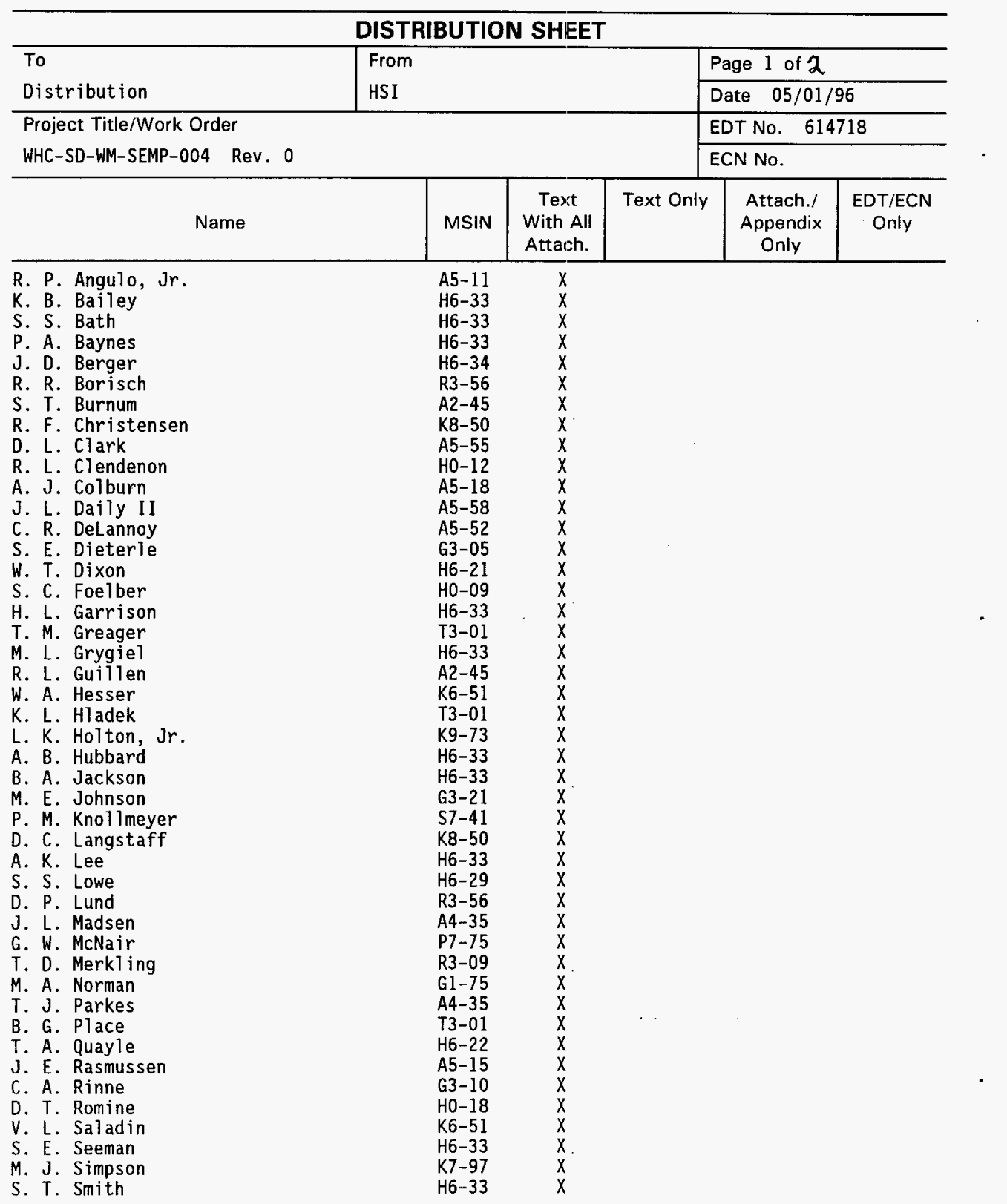



J. D. Thomson
W. E. Toebe
D. E. Trader
M. B. Triplett
C. F. Wagner
J. L. Waite
S. H. Wisness
J. C. Womack
Central Files

H6-33

$\mathrm{H} 6-22$

K8-50

$x$

K9-09

A2- 45

H6-33

A5-18

R3-86

Page 2 of ?

EDT-574718

!!HC-SD-WM-SEMP-004

Revision 0

A3- 88 